NBER WORKING PAPER SERIES

\title{
SHORT AND LONG RUN UNCERTAINTY
}

\author{
Jose Maria Barrero \\ Nicholas Bloom \\ Ian Wright
}

Working Paper 23676

http://www.nber.org/papers/w23676

\author{
NATIONAL BUREAU OF ECONOMIC RESEARCH \\ 1050 Massachusetts Avenue \\ Cambridge, MA 02138 \\ August 2017
}

We thank seminar participants at Stanford, the 2015 World Congress of the Econometric Society, and the 2016 SED Annual Meeting for helpful comments. We thank the National Science Foundation, Sloan Foundation and SIEPR for providing generous research support. Ian Wright is a full-time employee of an affiliate of Goldman Sachs \& Co. He receives compensation in the form of cash and equity exceeding $\$ 5000$ per annum. This paper was written in Ian Wright's individual capacity and not related to his role at Goldman Sachs. The analysis, content and conclusions set forth in this paper are those of the authors alone and not of Goldman Sachs \& Co., any of its affiliate companies, nor of the National Bureau of Economic Research. The authors alone are responsible for the content.

At least one co-author has disclosed a financial relationship of potential relevance for this research. Further information is available online at http://www.nber.org/papers/w23676.ack

NBER working papers are circulated for discussion and comment purposes. They have not been peer-reviewed or been subject to the review by the NBER Board of Directors that accompanies official NBER publications.

(C) 2017 by Jose Maria Barrero, Nicholas Bloom, and Ian Wright. All rights reserved. Short sections of text, not to exceed two paragraphs, may be quoted without explicit permission provided that full credit, including $(\mathrm{C}$ notice, is given to the source. 
Short and Long Run Uncertainty

Jose Maria Barrero, Nicholas Bloom, and Ian Wright

NBER Working Paper No. 23676

August 2017

JEL No. E22

\begin{abstract} reducing $R \& D$ and investment.

Jose Maria Barrero

Economics Department

579 Serra Mall

Stanford University

Stanford CA 94305

barreroj@stanford.edu

Nicholas Bloom

Stanford University

Department of Economics

579 Serra Mall

Stanford, CA 94305-6072

and NBER

nbloom@stanford.edu

\author{
Ian Wright \\ Goldman Sachs \\ Peterborough Court \\ 133 Fleet St, \\ London EC4A 2BB \\ UK \\ iwright@stanford.edu
}

Uncertainty appears to have both a short-run and a long-run component, which we measure using firm and macro implied volatility data from options of 30 days to 10 years duration. We ask what may be driving uncertainty over these different time horizons, finding that oil price volatility is particularly important for short-run uncertainty, policy uncertainty is particularly important for long-run uncertainty, while currency volatility and CEO turnover appear to equally impact shortand long-run uncertainty. Examining a panel of over 4,000 firms from 1996 to 2013 we find that $\mathrm{R} \& \mathrm{D}$ is relatively more sensitive to long-run uncertainty than investment, and in turn investment is relatively more sensitive to long-run uncertainty than hiring. In a simulation model we investigate the channels underlying this pecking-order response to long-run uncertainty, and show that lower depreciation rates and higher adjustment costs lead R\&D and investment to be more sensitive to longer-run uncertainty than hiring. Collectively, these results suggest that recent events that have raised long-run policy uncertainty may be particularly damaging to growth by 


\section{Introduction}

Uncertainty has received substantial attention as a potential factor shaping aggregate economic outcomes. For example, the Federal Open Market Committee minutes repeatedly emphasize uncertainty as a key factor driving the 2001 and 2007-2009 recessions, while Stock and Watson (2012) state that "the main contributions to the decline in output and employment during the [2007-2009] recession are estimated to come from financial and uncertainty shocks."

In the summer of 2016 the world economy was rocked with one such uncertainty shock when the United Kingdom voted to leave the European Union. But the Brexit vote generated no uncertainty about the economic policies or fundamentals in place in the weeks and months immediately following the vote. Instead, the referendum results created huge questions about the future of the UK's trading relationships, the long-run immigration status of European Union citizens living in the UK and vice versa, and more broadly about the long-run outlook of the British, European, and global economies. Similarly, the election of Donald Trump to the US Presidency in November 2016 produced a dramatic rise in policy uncertainty, particularly over longer-run policies regarding trade, immigration, and healthcare reform.

This paper seeks to investigate whether short- and long-run uncertainty impact the economy equally by exploiting the information in the time profile of uncertainty across equity

options of different durations. Equity options are issued at a range of durations from 30 days to 2 years for individual equities and 30 days to 10 years for the overall S\&P 500 index, yielding firm and macro volatility curves. In Figure 1 we show some examples of the fluctuations in the macro volatility curve, using data that generalizes the well-known VIX (a 30-day implied volatility on the S\&P 500) to longer horizons. The changing level and slope of these volatility curves reflects fluctuations in the time profile of uncertainty, which could influence different firm decisions if their payoffs have distinct time profiles. For example, investment and $\mathrm{R} \& \mathrm{D}$ as longer-run decisions may respond more strongly to long-run uncertainty than hiring.

We begin by asking what drives short- versus long-run implied volatility at the firm level. Examining four factors that vary at the firm-quarter level - the price of oil, exchange rates, 
policy uncertainty. and CEO turnover - we find that oil-price uncertainty appears to play a particularly important role in shaping short-run uncertainty, reflecting perhaps that oil prices are a mean-reverting stochastic process ${ }^{1}$. In contrast, policy uncertainty has a larger impact on long-run uncertainty, which is perhaps not very surprising given the longer-run focus of many of the major policy debates of recent years, including discussions about the US debt ceiling, health-care, immigration reform and involvement in foreign wars. Finally, we find currencies and CEO turnover appear to impact both short-run and long-run uncertainty about equally.

To investigate the hypothesis that different firm policies react differently to short- versus long-run uncertainty, we build a panel dataset of over 4,000 firms from 1996 to 2013 combining firm and macro equity options data across a range of horizons and a range of real and financial variables. We find that investment, $R \& D$ activity, and employment are all significantly reduced by uncertainty, but investment and $R \& D$ are significantly more responsive to long-run uncertainty than employment. Furthermore, we argue that these relationships are causal by exploiting exogenous variation in economic policy uncertainty, oil price volatility, and currency volatility to instrument for long- and short-run uncertainty. The impact of both types of uncertainty on investment is also more pronounced for highly-levered firms, suggesting that high levels of debt and financial constraints may exacerbate the impact of long-run uncertainty. This finding is in accordance with recent evidence on the joint adverse effects of financial and uncertainty shocks, for example as found byAlfaro et al. (2015) and Caldara et al. (2016), with the added distinction about the relative impact of short- versus long-run uncertainty on different firm policies.

Finally, we use simulations with short- and long-run uncertainty processes to investigate what channels are responsible for the differential responses to short- and long-run uncertainty across investment, R\&D, and hiring. In a model with two factors - capital and labor - which are distinguished by capital having higher adjustment costs and lower depreciation rates, we find that the greater adjustment costs and (more importantly) the greater durability of capital make it more responsive to long-run uncertainty than hiring in the model. This highlights how factor inputs with low depreciation rates (like buildings and long-lived equip-

\footnotetext{
${ }^{1}$ See for example, Pindyck (1990)
} 
ment investments) and those with high adjustment costs (like intangibles and organizational capital) are going to be particularly sensitive to long-run uncertainty. As such, the recent increases in policy uncertainty in the US - again, a key driver of long-run uncertainty - may play a role in explaining the puzzlingly low level of aggregate investment (noted, for example, by Gutiérrez and Philippon (2016)), and low TFP growth rates (given the importance of intangible investment and R\&D for TFP growth) in recent years. Similarly, we predict that the United Kingdom might face depressed investment and growth in the years following the Brexit vote as long as there is outstanding uncertainty about the future of British economic policy and trading relationships.

Our paper relates most obviously to the empirical literature focused on the impact of uncertainty for investment (and to a lesser extent hiring) - for example, Bernanke (1983), Dixit and Pindyck (1994), Caballero et al. (1995) and Abel and Eberly (1996). It is also related to the empirical literature that studies the impact of real frictions on investment dynamics. For example, Leahy and Whited (1996), Guiso and Parigi (1999) and Bloom, Bond, and Van Reenen (2007) all provide evidence suggesting that firm-level uncertainty shocks reduce firms' investment and hiring, while Romer (1990), Ramey and Ramey (1995), Bloom (2009), Fernández-Villaverde et al. (2011) provide evidence suggesting macro uncertainty shocks appear to drive business cycle fluctuations ${ }^{2}$. However, none of this literature focuses on the difference between short-run and long-run uncertainty. Perhaps closer to our paper is the asset pricing literature examining the volatility curve, including Bekaert and Hoerova (2014) and Dew-Becker et al. (2015). In a closely related paper Berger et al. (2017) study whether aggregate realized volatility or expectations of future volatility are associated with contractionary movements in macro variables, finding that expectations about future macro volatility have a hard time explaining contractions after accounting for current realized volatility. Our approach differs from theirs in that we focus on the idiosyncratic volatility curve and on firm-level outcomes, where we find strong associations between the time profile

\footnotetext{
${ }^{2}$ See also Kehrig (2011)'s paper on countercyclical productivity dispersion; Christiano et al. (2014)'s, Arellano et al. (2012)'s and Gilchrist et al. (2014)'s papers on uncertainty shocks in models with financial constraints; work by Gilchrist and Williams (2005) on uncertainty, investment and capacity; Basu and Bundick (2012)'s paper on uncertainty shocks in a new-Keynesian model; Fernández-Villaverde et al. (2015)'s paper on fiscal policy uncertainty; Knotek II et al. (2011)'s paper on durable consumption and uncertainty; and Bachmann and Bayer (2013)'s paper on microeconomic level uncertainty with capital adjustment costs.
} 
of volatility and flow variables like investment and hiring.

We proceed by describing our data in Section 2, and then asking what drives shortversus long-run uncertainty in section 3. Section 4 presents the main empirical results on the response of investment, $R \& D$, and hiring to uncertainty, while Section 5 presents our model and simulation results. Section 6 concludes.

\section{Data and Measurement}

\subsection{Measuring Short- and Long-run Uncertainty}

We use data on option implied volatilities as our empirical measures of short- and long-run uncertainty at the macro and firm levels. Implied volatilities are calculated by taking option trading data and inferring what volatility in the value of the underlying would result in the observed option prices, often using an option pricing model (e.g. the Black-Scholes 1973 formula). Formally, an implied volatility measures the expected risk-neutral volatility in the price of the underlying asset over the horizon covered by the maturity of the option. Roughly speaking, if $\sigma(t)$ is a stochastic process for the volatility of a firm's share price, then the $T$-day implied volatility of the firm on date $t$ reflects the market's expectation of the

average volatility of the firm's share price over the life of the option: $\mathbb{E}_{t}\left(\frac{1}{T} \int_{t}^{t+T} \sigma_{i}(s) \mathrm{d} s\right)$. Often implied volatilities are considered forward-looking measures of uncertainty, precisely because they reflect market-based expectations about returns on the underlying security. The VIX, published by the Chicago Board of Options Exchange, is a well-known index of the 30-day implied volatility of the $\mathrm{S} \& \mathrm{P} 500$, and is often used as a proxy for measuring short-run US macro uncertainty.

In our empirical results we focus on firm-specific implied volatility, which can be estimated using options of any horizon, making it possible to measure expected uncertainty over a wide range of durations. We obtain individual firm implied volatility data from 1996 onwards from OptionMetrics, a database covering all exchange-listed options in the United States. They provide implied volatility figures for standardized options with horizons of 30, 60, 91, 152, 182, 273, 365, and 730 days, conditional on the firm having options trading at or beyond 
that maturity ${ }^{3}$. Throughout our empirical work we use the average of the put and call implied volatilities at each given duration, but our findings are robust to using either of the two instead, as the put and call implied volatility data are nearly identical. Because our data on firm financials is at an annual or quarterly frequency (see Section 2.2), we average daily implied volatility observations into a single uncertainty measure by firm-quarter or firm year. We will sometimes link a firm's investment behavior in a given quarter with the implied volatility measured in the previous quarter, to mitigate reverse causality concerns and to exploit the fact that implied volatilities are forward-looking measures of uncertainty. Analogously, our baseline estimates link firm-level observations in a given fiscal year with the average implied volatility in the last quarter of the previous fiscal year. However, for our IV specifications we use contemporaneous implied volatility, measured as the average for the quarter or year as appropriate.

Because firm equity options with longer maturities (especially for one year and beyond) are traded less frequently, implied volatility data at these longer horizons is often missing. This both decreases sample size when using these longer-run firm-level uncertainty measures, and also potentially raises issues about the selection of larger firms whose equity options trade at these longer horizons. To overcome these problems, we first document the stylized fact that volatility curves (the plot of volatility over different durations) are approximately linear, so we can approximate the entire volatility curve with two points, as is analogously done in finance with the term structure of interest rates, for example by Harvey (1988), Estrella and Hardouvelis (1991), and Ang and Piazzesi (2003). Our stylized fact is consistent with other papers in the the finance literature that focus on the term structure of variance swaps on the S\&P 500, and expectations about future stock market volatility, including Ait-Sahalia et al. (2015), Egloff et al. (2010), and Berger et al. (2017).

Starting with column (1) in Table 1 we show that the quarterly two-year firm-specific implied volatility (the longest duration at which firm equity options are commonly available) is well predicted by the corresponding level (30-day implied volatility) and slope (difference between the 6-month and 30-day volatilities) data, with an R-squared of 0.946. Hence, if we

\footnotetext{
${ }^{3}$ Option Metrics uses observed option trading data to provide information about theoretical "standardized" options, which are theoretical American put and call options with strike prices equal to at-the-money forward stock prices and fixed maturities. See Appendix B for more details.
} 
have data for the 30-day and 6-month implied volatilities for a firm - selecting the 30-day and 6-month durations as these are commonly traded - we can use them to proxy for the intercept and slope of the full (approximately linear) volatility curve. In columns (2) to (5) we repeat this exercise for daily observations of long-run macroeconomic uncertainty up to a five year horizon using the generalized VIX on the S\&P 500 index. This data came from Goldman Sachs based on replicating the methodology on the VIX on its entire portfolio of proprietary equity options ${ }^{4}$. Again we see consistent R-squared values above 0.9 , suggesting that the entire macro volatility curve can also be well described using only two data points. This strong linearity is shown graphically in Figure 2 which plots the 2-year and 5-year VIX against their fitted values from the regressions of the 30-day and 6-month VIX in columns (2) and (4), where we see both the good overall fit and the fact this fit appears equally good at low, medium and high levels of implied volatility.

In light of these findings, for our empirical work we will measure short-run and long-run uncertainty using only 30-day and 6-month implied volatility data, describing the volatility curve using a level term (30-day implied volatility) and a slope term (6-month-30-day volatility), again, as in the yield-curve literature.

\section{$2.2 \quad$ Firm-level Data}

We match our firm-specific implied volatility data to quarterly and annual financial data from Compustat, dropping firm-quarters and firm-years with negative book value of assets, negative sales or stockholders' equity, as well as those with missing capital expenditures. Our quarterly sample ranges from 1996Q2 to 2013Q1, while the annual sample covers 1997 to 2013. As is standard in the empirical literature on investment and uncertainty (e.g. Gulen and Ion (2013)), we exclude SIC codes corresponding to utilities and financials. The resulting matched dataset overrepresents large and fast-growing firms as these are the firms with a sufficient volume of equity option transactions for Option Metrics to provide implied

\footnotetext{
${ }^{4}$ The "true" VIX published by the Chicago Board Options Exchange and is a model free measure of the risk neutral implied volatility of the S\&P 500 index over the next 30 days. It is computed specifically for that horizon. However, the formula can be generalized to compute a VIX for various horizons, using variance swaps or options. Our generalized VIX data was generously provided by Goldman Sachs, for reasons unrelated to Ian Wright's employment with them. For details on the VIX, see CBOE (2009).
} 
volatility estimates. See Appendix Table 1 for summary statistics on the matched quarterly and annual samples, and Appendix Table 2 for some results on which firms have non-missing data on 30-day and 6-month implied volatility.

We measure investment as firms' capital investment rate (capital expenditures per existing unit of capital). Given our large firm sample we have no negative or zero investment rates so we take logs to reduce the influence of large outlier investment rates. To measure quarterly R\&D activity we first impute quarterly R\&D expenditures (XRD) to be zero whenever a firm's R\&D expenditures are missing but were previously positive ${ }^{5}$. Then we construct R\&D growth as our main measure of R\&D activity. Similarly, we measure hiring as the growth in the reported number of employees across years. We construct standard first-moment controls in both our quarterly and annual datasets, including the ratio of cash flows (i.e. operating income) to assets, Tobin's $q$ (the ratio of the firm's enterprise value to the book value of it's assets) and sales growth.

Following Davis, Haltiwanger and Schuh (1996), we measure all growth rates (in the number of employees, sales, or R\&D expenditures) as the change in stock variable $x_{t}$ between years $t-1$ and $t$, divided by the average of the two years (with two consecutive periods of zero given a zero growth rate). DHS growth rates are well-known to approximate the logchange for small growth rates, are symmetric around zero, and accommodate entry and exit with bounded values of plus and minus two. The latter property is especially important for R\&D expenditures, where it is conceivable that even Compustat firms may go from having positive $R \& D$ to zero (and vice versa) from one quarter to the next.

\section{What Drives Short- and Long-run Uncertainty?}

In the preceding pages we have argued that variation in the level and slope of firm-specific volatility curves reflects the market's uncertainty about the firms' short- and long-run prospects.

\footnotetext{
${ }^{5}$ For example, if a firm did not report R\&D until 2005, reported positive R\&D from 2005 to 2010, and then stopped reporting R\&D after 2010 we would impute zero R\&D from 2011 onwards (but leave pre-2005 data as missing). This assumes that post 2010 this was a conscious decision not to report R\&D but pre 2005 the data could genuinely have been missing. The reason for this approach is that the reporting of R\&D expenditure by firms has been increasing over time due to more rigorous accounting standards and more generous tax treatment of R\&D.
} 
But what are the economic reasons leading market actors to perceive the volatility of firm equity to be high or low for any given horizon? In this section, we construct firm- and sectorspecific measures of exposure to several sources of uncertainty, including economic policy, oil prices, and changes in management. Then we ask whether these exposure measures are differentially associated with short- or long-run uncertainty, shedding some light on what may drive fluctuations in the term structure of uncertainty.

\subsection{Data on Uncertainty Drivers}

We focus on a set of drivers of firm-level uncertainty which can be measured at a monthly basis. In particular, we focus on oil and currency price volatility as suggested by Stein and Stone (2013) and Alfaro et al. (2015), economic policy uncertainty (EPU) as measured by Baker, Bloom, and Davis (2016), and CEO turnover as implied by Bertrand and Schoar (2003)'s work highlighting the importance of CEOs for company performance. We acknowl-

edge that there are potentially many other factors driving idiosyncratic firm-level volatility, with our focus on these four driven by data availability. However, these four factors do capture a number of the key drivers of firm-level uncertainty, and also highlight their differential impacts on short- and long-run uncertainty.

We construct sector-level exposure to oil and currency price volatility using a two-step procedure. First, we estimate the sensitivity of individual stock returns to oil and currency price fluctuations by two-digit SIC industries, controlling for firm fixed effects and market returns. We estimate the following equation for the daily stock returns of firm $i$ in sector $j$ and date $t$ :

$$
r_{i j t}=\alpha_{i}+\beta_{j m} r_{m t}+\beta_{j o} r_{\mathrm{oil} t}+\Sigma_{k} \beta_{j k} r_{k t}+\varepsilon_{i t}
$$

Here $r_{m t}$ are returns on the $\mathrm{S} \& \mathrm{P} 500, r_{\text {oilt }}$ are oil price returns, and $r_{k}$ are returns from holding currency $k$, while $\alpha_{i}$ is a vector of firm fixed effects. The data on stock returns comes from CRSP, and oil price and exchange rate data from Bloomberg. We use data from 7 currencies which the Federal Reserve Board has designated as "major" currencies and which it uses to construct the nominal and real trade-weighted U.S. Dollar Index of Major 
Currencies $^{6}$. Our coefficients of interest are $\beta_{j o}$ and each of the $\beta_{j k}$ 's (one for each particular currency), which capture the sensitivity of stock returns of firms in industry $j$ to fluctuations in oil prices and exchange rates, respectively. We run this regression on a pre-sample period ranging from 1985 to 2004 and assume that the estimated sensitivities carry over to our main sample period from 2005 onwards. This ensures that our estimated sensitivities are not dependent on the data in that main sample. In the baseline setup we estimate the sensitivities by SIC-2 industry, restricting attention to sectors that have data for at least 20 firms during the estimation period.

The second step in constructing volatility exposure variables involves multiplying the absolute value of each industry's sensitivity by a measure of the volatility of the commodity or currency in question. We use the log of 30-day implied volatility for oil and each of our currencies (obtained from Bloomberg and averaged over a calendar month), and construct an overall measure of currency volatility exposure by adding up over the individual currencies:

$$
\begin{gathered}
\text { OilVolExposure }_{i j t}=\left|\hat{\beta}_{j o}\right| \cdot \log \left(\sigma_{o t}\right) \\
\text { CurrVolExposure }_{i j t}=\sum_{k}\left|\hat{\beta}_{j k}\right| \cdot \log \left(\sigma_{k t}\right) .
\end{gathered}
$$

In constructing these variables, we attempt to capture the fact that certain industries might be differentially exposed to fluctuations in exchange rates and commodity prices, having controlled for overall market and firm conditions. For example, the air travel and oil and gas sectors might be differentially exposed (respectively, negatively and positively) to oil price movements. When oil prices are more volatile, these more exposed sectors should perceive significant oil uncertainty, especially in comparison with other sectors that are less exposed to oil. We therefore multiply our measure of oil price uncertainty by the absolute value of

\footnotetext{
${ }^{6}$ See https://www.federalreserve.gov/pubs/bulletin/2005/winter05_index.pdf. The seven currencies are Canadian Dollar, Japanese Yen, Euro (or European Currency Unit prior to 1999), Australian Dollar, Swedish Krona, Swiss Franc, British Pound. The same set of currencies is used in Alfaro et al. (2015).
} 
the sensitivity. Firms in highly exposed sectors will be highly affected by oil price volatility regardless of whether they benefit from higher or lower oil prices. The same logic applies for firms in sectors that are exposed to one or another major foreign exchange market. For example, domestic atomobile manufacturing may be highly affected by fluctuations in the Japanese Yen due to significant competition from Japanese firms, and in our measure will be particularly exposed to volatility on the Yen-Dollar exchange rate.

Data on monthly firm-specific exposure to economic policy uncertainty (EPU) comes from Baker et al. (2016). This variable is constructed by first scaling an industry's share of revenues from Federal Government contracts by the aggregate news-based EPU index. Then, individual firms are assigned to an industry according to their firm-level line of sales data, so this results in a firm-by-month policy uncertainty index ${ }^{7}$. Interested readers are referred to the original article for more details on this procedure.

Data on executive turnover comes from Execucomp, a database containing information on top executives in Compustat firms, in particular listing the dates during which CEOs held office. This is a simple way of capturing an idiosyncratic event with potentially significant repercussions to the firm's future, and potentially affecting the market's uncertainty about the firm.

\subsection{Drivers Results}

We study how oil and currency volatility, economic policy uncertainty, and CEO turnover are associated with short- and long-run uncertainty at the firm level by regressing monthly measures of firm implied volatility on each of the drivers we consider, including firm and date fixed effects. Table 2 displays the results, with the top section referring to regressions that use the logarithm of 30-day implied volatility as the dependent variable, with the middle section using the logarithm of the 6-month implied volatility, and the slope (the difference) in the bottom section.

Starting with the top panel focusing on short-run 30-day implied volatility we see individ-

\footnotetext{
${ }^{7}$ Following Baker et al. (2016) when we use EPU exposure as a right-hand-side variable, we also include a control that interacts federal spending as percent of GDP with firm's exposure to government purchases (again, based on line-of-business data) to control for the direct effect of fiscal policy changes on volatility.
} 
ually in columns (1) to (4) and jointly in column (5) that these factors are all positively correlated with uncertainty. In particular, CEO turnover is highly significant and oil-exposure is weakly significant, but has an extremely large (and robust) coefficient. In the middle-panel we look at each of the drivers' association with the longer-run (6 month) implied volatility and again see that individually all of economic policy uncertainty, oil, currency and CEO turnovers factors are positively associated with uncertainty, with quantitatively similar results in the joint specification of column (5). Again we see the CEO turnover variable is highly significant, but now the oil volatility exposure is about $1 / 3$ of the magnitude from the top-panel, while the policy-uncertainty measure is significant at the $10 \%$ level in both the individual joint specifications.

Finally, in the bottom panel we examine the drivers' predictive power for the slope of uncertainty defined as 6-month less 30-day implied volatility. Again, we see that policy uncertainty loads positively, highlighting its greater role in explaining variations in the relative amount of long-run versus short-run uncertainty, while oil volatility loads negatively and significantly suggesting short-run uncertainty is more related to oil (and more generally energy price) uncertainty. Currency and CEO turnover have very low coefficients suggesting they have a roughly proportional impact on short-run and long-run uncertainty, so shift the entire volatility curve up or down.

Overall our results are intuitive, suggesting that slow-moving and potentially more radical drivers like economic policy are linked to long-run uncertainty. By contrast, oil price volatility might impact firms' bottom lines much more quickly and perhaps transitorily, explaining why it is closely associated with short-run uncertainty. These results will help us interpret why investment, hiring, and R\&D might react differently to movements in short- versus longrun uncertainty. Moreover, we argue that these drivers are relatively exogenous from the perspective of individual firms (especially policy, oil, and currencies) so we can use them as instruments to argue that changes in short- and long-run uncertainty cause changes in firm behavior. 


\section{Investment and Hiring under Short-Run and Long-run Uncertainty}

In this section we document our main empirical findings that the investment, R\&D activity, and hiring behavior of large, publicly-traded firms in the US is negatively impacted by both short- and long-run uncertainty. The sensitivity of each of these activities to short- versus long-run volatility differs, however. R\&D activity responds relatively more negatively to long-run uncertainty than capital, which in turn is more responsive than hiring. Finally we document that this response to long-run uncertainty is mainly driven by more highly-levered firms. Replication files for all the empirical results are available online at this link.

\subsection{Specification and Identification}

We study the empirical relationship between investment, hiring and R\&D against shortversus long-run uncertainty by estimating equations of the form

$$
\begin{gathered}
Y_{i, t}=\alpha_{i}+\gamma_{t}+\beta_{1} \log \left(30 d I V O L_{i, t}\right)+\beta_{2}\left(\log \left(6 m I V O L_{i, t}\right)-\log \left(30 d I V O L_{i, t}\right)\right) \\
+\delta_{1} Q_{i, t-1}+\delta_{2} C F_{i, t} / A_{i, t-1}+\delta_{3} G_{i, t}+\varepsilon_{i, t}
\end{gathered}
$$

where $i$ indexes firms and $t$ indexes quarters or years depending the specification, $Y_{i, t}$ is one of our outcome variables, namely one of investment, net hiring, or growth in R\&D expenditures, $\alpha_{i}$ is a vector of firm fixed effects, $\gamma_{t}$ is a vector of date fixed effects, $30 d I V O L_{i t}$ and $6 m I V O L_{i t}$ are the 30-day and 6-month implied volatilities associated with firm $i$ on date $t$. In turn, $Q_{i, t}, C F_{i, t} / A_{i, t-1}$, and $G_{i t}$ are Tobin's $q$, the ratio of current cash flows to book value of assets, and sales growth ${ }^{8}$.

We begin our empirical analysis by considering conditional correlations between our outcome variables and short- and long-run uncertainty, shown in Table 3. To mitigate some of the more immediate threats to identification we use lagged uncertainty for these OLS

\footnotetext{
${ }^{8}$ Tobin's $q$ is the ratio of the firm's full enterprise value (common and preferred stock capital plus current and long-term liabilities) over the book value of assets. Cash flow is measured as income from operating activities, and sales growth is measured as the difference over the average of sales in the past year and the previous year following Davis, Haltiwanger, and Schuh (1996).
} 
specifications, and always include the above-named first moment controls, namely Tobin's $q$, cash flow ratio, and sales growth, as well as a full set of firm and date fixed effects. We acknowledge that these variables cannot control for all unobserved first-moment determinants of investment that may be correlated with short- and long-run uncertainty, so this is more of a descriptive exercise.

To obtain causal evidence of the impact of short- and long-run uncertainty, we later re-estimate equation 3 treating our implied volatility variables as endogenous included regressors, using changes in firms' exposure to policy uncertainty, oil price volatility, and currency volatility as excluded exogenous instruments. This identification strategy is guided by our finding in Section 3 that firm-specific short- and long-run uncertainty are associated with firms' exposure to our chosen instruments. We also argue that fluctuations in policy uncertainty, currency and oil markets are exogenous from the point of view of individual firms in Compustat ${ }^{9}$. Results from this second exercise are in Table 4.

\subsection{Empirical Results}

Starting with the OLS results, in Table 3 column (1) we consider the link between quarterly investment measured as the ratio in logs of quarterly capital expenditures (CAPX) per unit of perpetual inventories capital on the level of uncertainty proxied by the log of 30 day implied volatility, and the slope of the volatility curve measured as the log difference between 30 day and 6 month implied volatility. The specification also includes all of our first moment controls and a full set of firm and date fixed effects. We see that both the level and slope coefficients are negative, suggesting both short-run and long-run uncertainty are negatively associated with capital investment.

In column (2) we turn to the relationship between growth in $R \& D$ expenditures and short- and long-run uncertainty, finding now that R\&D activity is quantitatively much more responsive to long-run uncertainty. This result speaks to a strong deceleration in the growth of $R \& D$ expenditures in the presence of long-run uncertainty, which is intuitive if we believe

\footnotetext{
${ }^{9}$ Although we also found in Section 3 that CEO turnover is highly associated with both short- and longrun firm-level uncertainty, we do not use it as an instrument, since we believe that it fails the exclusion restriction. Namely, CEO transitions may impact the market's uncertainty about the firm and also directly impact the firm's investment, hiring, and R\&D choices.
} 
that there are flow adjustment costs to R\&D, say, because it is hard to fire scientists or scale down the costs associated with running laboratories, and the payout of this R\&D materializes slowly. Then, high long-run uncertainty makes it undesirable to commit to high levels of R\&D spending that cannot be easily scaled down even in the far-off future. We also find that R\&D growth is more strongly associated with long-run uncertainty than investment by using the difference between the two as the dependent variable in column (3), with the strong negative coefficient on the slope term meaning that firms seem to decelerate their R\&D expenditure growth more strongly than they adjust their investment rates ${ }^{10}$.

We move on to look at hiring in column (5) and find that it is also negatively associated with the level and slope of the firm's volatility curve. This specification is at an annual frequency since employment is not reported quarterly in Compustat. The relevant finding is that hiring declines less than investment when long-run uncertainty is relatively high, which we see in column (6) when we use the difference between annual investment and hiring as the outcome of interest. This result suggests that there is a hierarchy in terms of the effects of long-run uncertainty, with the largest response in R\&D growth, then investment, and finally the smallest decline in hiring. The simulation exercises in section 5 will show that differences in the rate of depreciation across asset classes can help explain this pattern, whereby long-lived and less adjustable assets are more responsive to long-run uncertainty. Thus, when uncertainty shocks occur that particularly increase long-run uncertainty this will tend to disproportionately reduce investment, lowering the capital-labor ratio. As we discussed in the introduction, the current low levels of investment in the US could be due in part to the high levels of policy uncertainty, which as we saw in the previous section is more closely related to long-run uncertainty. Our result that R\&D responds even more strongly than investment to short- and long-run uncertainty furthermore suggests that high levels of policy uncertainty and long-run uncertainty could have particularly detrimental effects on innovation and aggregate productivity growth.

Turning to Table 4, we repeat the entire exercise from Table 3, but this time treating

\footnotetext{
${ }^{10}$ Interestingly, Stein and Stone (2013) find a positive coefficient for R\&D on uncertainty, but they examine the level rather than the growth rate of $\mathrm{R} \& \mathrm{D}$ expenditure. We think the growth rate is the correct variable for symmetry with the change in investment and employees, and because this focuses on the short-run response of factor inputs to increased uncertainty as the literature has focused on, following the early theory and empirical papers like Dixit and Pindyck (1994) and Leahy and Whited (1996).
} 
the level and slope of the firm-specific volatility curves as included endogenous regressors and using oil price volatility, currency volatility, and economic policy uncertainty (EPU) as exogenous instruments. The results from this exercise essentially confirm our OLS results, but now with a causal interpretation. We estimate a strong negative impact of long-run uncertainty on investment in column (1), but this effect is dwarfed quantitatively speaking by an even stronger impact on R\&D growth as seen in column (2). The results from the difference between the two in column (3) have the right sign and magnitude, but are insignificant perhaps because R\&D has a small sample, reducing the power of the instruments. Turning to hiring and the difference between investment and hiring, the story is similar, although the results are somewhat weak as the instruments are less powerful at an annual frequency. The point estimate for the impact of long-run uncertainty on hiring is quantitatively higher than for short-run uncertainty, but the latter is more statistically significant, and similarly when looking at the difference between investment and hiring in column (6) we confirm that the signs coincide with the OLS specification in indicating that investment is relatively more responsive to long-run uncertainty even if not significant.

\subsection{Leverage and Uncertainty}

In Table 5 we explore how the negative relationship between short- and long-run uncertainty and each of our outcome variables differs for firms with high versus low leverage. For this exercise, we measure leverage for each firm-quarter (or firm-year) as the ratio between the firm's total assets and the difference between total assets and the sum of both current and long-term debt liabilities:

$$
\text { Leverage }_{i, t}=\frac{\text { Asset }_{i, t}}{\text { Assets }_{i, t}-\left(\text { DebtLongTerm }_{i, t}+\text { DebtCurrent }_{i, t}\right)}
$$

- Columns (1), (4), and (7) reproduce the baseline OLS results from Table 3 in which we regress investment, growth in $R \& D$ expenditures, and hiring on the level and slope of firms' volatility curves. Then we proceed to split the firms in each sample by whether they have higher or lower leverage than the median firm in our Compustat sample. For each of investment, R\&D growth, and hiring, the subsample with highly levered firms seems to 
be driving the negative relationship between these firm-level outcomes and both short- and long-run uncertainty. Indeed, the coefficients on both kinds of uncertainty in columns (3), (6), and (9) are more negative than those in columns (2), (5), and (8), and in the case of $\mathrm{R} \& \mathrm{D}$ and hiring, more statistically significant.

This result that more highly-levered firms exhibit larger declines in investment, $R \& D$, and hiring in times of higher short- and long-run uncertainty makes sense if we interpret leverage as a measure of firms' financial constraints. The real options effects that impact firms' forward-looking investment decisions should be more relevant for firms that are more constrained and therefore have an even smaller appetite for risky ventures. This sort of dynamic whereby uncertainty shocks are particularly damaging during times of tightened financial constraints has been also documented empirically elsewhere, for example by Alfaro et al. (2015) and Caldara et al. (2016). We additionally find that this relationship holds for changes in both the level and slope of firm-specific volatility curves. So firms with high levels of debt relative to assets are even more prone to cutting investment, new R\&D projects, and hiring when their long-run prospects seem particularly volatile. This is intuitive, as longlasting and more irreversible investments may be more likely to require debt financing and might also have more significant implications for firms' balance sheets.

\subsection{Robustness Checks}

In Table 6 we show that our baseline OLS and IV results on investment are robust to various modifications in the specification. To begin, we reproduce this baseline specification from Tables 3 and 4, shown here, respectively, in columns (1) and (5) for the OLS and IV results.

In columns (2) and (6) we include lagged investment as an additional control to capture the fact that capital expenditures in the current quarter may have been planned for some time, meaning that lagged investment is predictive of current investment and potentially correlated with our (also lagged) measures of short- and long-run uncertainty. However, upon examination it is clear that this is not driving the result for either the OLS or IV regressions.

In the remaining columns we test the validity of using 6-month implied volatility to proxy for long-run uncertainty, instead using 1-year and 2-year implied volatility. The latter is the 
longest horizon for which we have implied volatility for individual firms' equity. In the OLS case, displayed in columns (3) and (4), the point estimates are similar for the level of shortrun uncertainty, if less significant due to smaller sample sizes. The coefficient on long-run uncertainty is somewhat larger than in the baseline, which is qualitatively consistent with investment being particularly sensitive to long-run uncertainty; however, the standard errors are fairly large, again, as a consequence of the sample size. In the IV case, seen in columns (7) and (8) we see that the result is pretty robust and even stronger in terms of statistical significance, despite the sample being cut by more than half with respect to the baseline in column (5).

\section{Simulation}

We develop a firm-level partial equilibrium model to help interpret our prior results on the differential sensitivity of R\&D, investment, and employment to short- and long-run uncertainty. The model is based on a canonical setup like that considered in Chapter 8 of Adda and Cooper (2003), but features two input factors - capital and labor -, rich adjustment costs, and time-varying uncertainty. Moreover, we allow this firm-specific uncertainty to have both a short-run and a long-run component. We do not include R\&D in this baseline model because of the complexity of having three input factors with three investment decisions alongside a first moment driving process plus short and long-run uncertainty, but the implications from the comparison of investment and hiring will naturally carry over to the $\mathrm{R} \& \mathrm{D}$ case.

Solving the model numerically for data-calibrated parameters, we investigate the impact of short- and long-run uncertainty on firm activity on a panel of simulated data. Consistent with the empirical results from Section 4, firms stop investing and hiring in reaction to both

short- and long-run uncertainty, but investment drops relatively more than hiring in reaction to long-run uncertainty. We show that the longer life and greater irreversibility of capital in the model are responsible for these patterns. Replication files are available online at this link. 


\subsection{A Two-Factor Model: Capital versus Labor}

Firms are assumed to consist of a number of production units, each making the intertemporal decision to invest and hire workers. On date $t$ each production unit has access to a reduced-form supermodular revenue-generation function based on an underlying CobbDouglas physical production function, assuming that other inputs (e.g. materials) are optimized out statically:

$$
R\left(A_{t}, K_{t}, L_{t}\right)=A_{t} K_{t}^{\alpha_{k}} L_{t}^{\alpha_{l}}
$$

$A_{t}$ is a stochastic Hicks-neutral shock to revenue-generating capacity, which we assume to be log-normal and follow an $A R(1)$ process with stochastic volatility:

$$
\log A_{t}=\rho_{A} \log A_{t-1}+\sigma_{t} \varepsilon_{t}, \quad \varepsilon_{t} \sim \mathcal{N}(0,1)
$$

We introduce short- and long-run uncertainty to the model by letting $\sigma_{t}^{2}$, the variance of innovations to $\log A$, to be the sum of a short-run and a long-run component:

$$
\sigma_{t}^{2}=\sigma_{s, t}^{2}+\sigma_{l, t}^{2}
$$

The two volatility components, $\sigma_{s}$ and $\sigma_{l}$, follow independent, symmetric Markov chains on two points (i.e. a high and a low state), with the persistence of $\sigma_{l}$ being higher than for $\sigma_{s}$. In the simulation we assume production units within a firm have a common volatility process, while innovations to $\log A$, are drawn independently across units within a firm.

Production units choose to invest in new capital and hire workers, both of which become immediately available for production. Capital depreciates at a rate $\delta_{k}$ and workers quit at a rate $\delta_{l}$, yielding the following laws-of-motion for $K$ and $L$ :

$$
\begin{aligned}
K_{t} & =\left(1-\delta_{k}\right) K_{t-1}+I_{t} \\
L_{t} & =\left(1-\delta_{l}\right) L_{t-1}+H_{t}
\end{aligned}
$$

We assume that $\delta_{l} \geq \delta_{k}$, making $K$ longer-lived than $L$. Investment and hiring are both 
subject to adjustment costs due to partial irreversibility (capital resale and layoffs result in a loss of $1-\gamma_{k}, 1-\gamma_{l}$, respectively of the value of $K$ and $L$ ), and are also subject to fixed adjustment costs denoted $F_{k}$ and $F_{l}$. By assumption, $K$ has also higher adjustment costs than $L$, i.e. $\gamma_{k} \geq \gamma_{l}$, and $F_{k} \geq F_{l}$. These differences in the life of potential investments, as well as the cost of (especially, downward) adjustability are the key elements of the model that drive firms' different reactions to short- versus long-run uncertainty.

Production units decide every period how much to invest in each of $K$ and $L$ so as to maximize the net present value of cash flows, bearing in mind their current first-moment state $A$, latest stock of $K$ and $L$, and the current state of the persistent and transitory volatility processes $\sigma_{s}$ and $\sigma_{l}$. The complete recursive problem can be stated as follows:

$$
\left.\begin{array}{rl}
V\left(A_{t}, K_{t-1}, L_{t-1}, \sigma_{s, t}, \sigma_{l, t}\right) & =\max _{I_{t}, H_{t}}\left\{\begin{array}{r}
A\left(K_{t-1}\left(1-\delta_{k}\right)+I_{t}\right)^{\alpha_{k}}\left(L_{t-1}\left(1-\delta_{l}\right)+H_{t}\right)^{\alpha_{l}} \\
-C\left(I_{t}, H_{t}, K_{t-1}, L_{t-1} ; \gamma_{k}, \gamma_{l}, F_{k}, F_{l}\right) \\
\text { s.t. }
\end{array}\right. \\
K_{t}= & \left(1-\delta_{k}\right) K_{t-1}+\mathbb{E}_{t}\left[V\left(A_{t+1}, K_{t-1}\left(1-\delta_{k}\right)+I_{t}, L_{t-1}\left(1-\delta_{l}\right)+H_{t}, \sigma_{s, t+1}, \sigma_{l, t+1}\right)\right]
\end{array}\right\}
$$

\subsection{Calibration, Numerical Solution and Simulation}

We calibrate the model taking standard parameter values from the literature, when possible, and trying to choose reasonable ones when there is no consensus. We make the revenue elasticities of $K$ and $L$ both equal to 0.4 in the model, consistent with constant returns to scale in the physical production function, equal coefficients on $K$ and $L$, and $25 \%$ markups. We make the revenue elasticity of both inputs equal in order to focus on how the differential adjustability and long-livedness of each generate differential sensitivity to short- and long- 
run uncertainty. The capital and labor depreciation/attrition rates $\delta_{k}$ and $\delta_{l}$ are set to $20 \%$ and $45 \%$ on an annual basis respectively, noting that given the stationary nature of the TFP process this also needs to account for output growth. The irreversibility on $K$ is set to $25 \%$, with $L$ being twice as downward adjustable. The full parameterization is in Appendix Tables 3 , with the model period set to be one month to allow for within quarter variation.

The recursive optimization problem is fairly standard, so we solve it via conventional policy iteration on a state space for $\left(A, K, L, \sigma_{s}, \sigma_{l}\right)$ of $(5,42,42,2,2)$. Having found the optimal investment policy for each element of the state space, we simulate a panel of 5,000 firms, each consisting of 25 production units that face the investment decision every month. The choice of 25 units per firm should be interpreted as a stand-in for some large number of divisions, offices, etc. within a firm. Again, each unit experiences idiosyncratic shocks to revenue-generating ability $A$, but the volatility $\sigma_{t}$ of first moment shocks is common across units within a firm. The simulation is run for 360 months (30 years), but we discard the first 300 (25 years) to remove the influence of initial conditions. Then we aggregate monthly firm-level figures into quarterly and annual data, measuring stock variables like $K$ and $L$ as the sum across all units of the firm at the end of the period. For flow variables like gross investment and cash flow we take the sum across units and across months within a year or quarter. As a last step in generating our simulated dataset, we add 5\% measurement error to all of the simulated data to proxy for the noise in real data.

To measure short- and long-run uncertainty for each firm-month in the simulation, we use the average expected volatility $\hat{\sigma}$ over the next $S$ or $L$ months, respectively:

$$
\hat{\sigma}_{S, t}=\mathbb{E}_{t}\left[\frac{1}{S} \sum_{m=1}^{S} \sigma_{t+m}\right] \quad \text { and } \hat{\sigma}_{L, t}=\mathbb{E}_{t}\left[\frac{1}{L} \sum_{m=1}^{L} \sigma_{t+m}\right], \quad \text { where } \quad \sigma_{t}=\sqrt{\sigma_{s, t}^{2}+\sigma_{l, t}^{2}} \text {. }
$$

We choose to measure uncertainty in this manner for analogy with option implied volatility, our uncertainty proxy in the empirical sections of the paper. Implied volatility captures the expected future uncertainty about the value of an asset over a given horizon that depends on the maturity of the options used to calculate the implied volatility (see section 2.1). Our baseline choices for $S$ and $L$ are 1 and 24 months, respectively, but our analysis is robust to 
using 1 and 6 months, which are the implied volatility horizons we consider in the empirical sections of the paper. As with the rest of the simulated data we average monthly uncertainty measures by quarter, but we take a firm's level of short- and long-run uncertainty in year $t$ with the average $\hat{\sigma}_{s, t}$ and $\hat{\sigma}_{l, t}$ during last quarter in the year. This is analogous to our treatment of the empirical implied volatility data (again, see Section 2 for details).

\subsection{Simulation Results}

The model generates a tight negative relationship between capital investment and both short- and long-run uncertainty. In Table 7 we regress the quarterly net investment rate on lagged expected volatility (in logs) using 30-day, 6-month, and 2-year horizons, including first moment controls and firm and date fixed effects ${ }^{11}$. Columns (1) through (3) document that our simulated investment series is negatively linked to uncertainty at all three horizons. In columns (4) and (5), we again regress logged investment on both the level of short-run (30-day) expected uncertainty, and the slope uncertainty time profile, alternatively using 6 months or 2 years as the long-run horizon. The results indicate strong negative links between investment and both the level and slope, suggesting that firms invest less intensively when the overall level of uncertainty is high, and also when uncertainty over longer horizons is higher than in the short run. Qualitatively, whether we take 6 months or 2 years as the long-run uncertainty horizon makes little difference, so henceforth we focus on 6 months as the long-run horizon, for analogy with the empirical work. Including additional first-moment determinants of investment, specifically ones that mirror those used in the empirical section, does not qualitatively change the results.

In Table 8 we investigate how uncertainty impacts investment in capital versus hiring. We focus on differences in net investment versus net hiring in the presence of short- and long-run uncertainty. All specifications in Table 6 include firm and date fixed effects and the first moment controls we use in the empirical section, namely the simulation counterparts to Tobin's $q$ (value/assets), cash flow (operating profits), and sales (output) growth. The results

\footnotetext{
${ }^{11}$ We define net investment as the growth rate of the firms' capital measured following Davis et al. (1996) as the difference across periods divided by the average. Our simulation results are all similar whether we use "gross" or "net" investment as an outcome variable.
} 
in columns (1) and (2) document negative relationships between investment and hiring and both short- and long-run uncertainty. The magnitudes of the coefficients, however, suggest that investments in $K$ decline more strongly when long-run uncertainty is high relative to short-run uncertainty. Hiring, by contrast, seems mostly sensitive to the level uncertainty, but not significantly linked to the degree of long- versus and short-run uncertainty.

In columns (3) to (5) we look more closely at this hypothesis by using relative capital investment less hiring as an outcome variable, and investigating what feature of the model is responsible by modifying the calibration. Starting with column (3), we see that in our baseline calibration investment and hiring seem to decline about equally with the level of short-run uncertainty, as the 30-day coefficient is small and insignificant. However, the negative coefficient on the slope term confirms that investment responds particularly negatively when long-run uncertainty is high relative to short-run uncertainty, but hiring does not. In column (4) we set the adjustment costs for labor equal to those for capital $\left(\gamma_{l}=\gamma_{k}\right)$ and find that the long-run effect falls by about half, with some offsetting short-run impact. So the greater irreversibility in investment relative to hiring contributes to investment's sensitivity to long-run uncertainty. Finally, in column (5) we equalize both durability and adjustability, setting the depreciation rate equal to the quit rate $\left(\delta_{k}=\delta_{l}\right)$, and confirm that both shortand long-run uncertainty are about equally linked to investment in both assets.

Overall, these experiments indicate that both the long-livedness of $K$ relative to $L$ and its higher adjustment cost contribute to the baseline result that $K$ investments seem particularly affected by higher long-run uncertainty. These insights imply that long-lived, costly to adjust assets - like buildings, long-lived equipment and R\&D - will likely be particular sensitive to long-run uncertainty. So these investments are going to be most acutely reduced, for example, by spikes in policy uncertainty.

\section{Conclusion}

Uncertainty appears to have both a short-run and a long-run component, which we investigate in this paper. To measure the time profile of uncertainty we use firm and macro implied volatility data from 30 days to 10 years duration for a panel of over 4,000 US firms. We 
show empirically that firms' long-run volatility is more closely linked with slow-moving and radical risks like those inherent to policy uncertainty, while short-run uncertainty is closely tied to oil price volatility. Moreover, there are other sources of firm-level uncertainty like CEO turnover and exchange rate fluctuations, which are associated with both short- and long-run uncertainty about equally.

We find that R\&D growth and investment are particularly sensitive to long-run uncertainty (with R\&D being the more sensitive of the two), while employment responds more equally to short- and long-run uncertainty. Furthermore, we verify the causality behind these relationships using exogenous variation in policy uncertainty, oil price volatility and exchange rate volatility to instrument for fluctuations in short- and long-run uncertainty. To investigate the channels responsible for these phenomena, we consider a model of investment and hiring and find that the lower depreciation rates of capital can largely explain why investment is more sensitive to longer-run uncertainty than hiring.

Our findings are significant in the wake of recent events like Britain's vote to leave the European Union and Donald Trump's assumption of the US Presidency, which have generated considerable uncertainty over future economic policy around the world. As we have shown, such policy uncertainty is particularly linked with long-run uncertainty and in turn with low rates of investment and R\&D that can have significant consequences for the global economic outlook in years to come.

\section{References}

Abel, A. B. AND J. C. EBerly (1996): "Optimal investment with costly reversibility," The Review of Economic Studies, 63, 581-593.

AdDA, J. AND R. W. CoOper (2003): Dynamic economics: quantitative methods and applications, MIT press.

Ait-Sahalia, Y., M. Karaman, And L. MAnCini (2015): "The term structure of variance swaps and risk premia," . 
Alfaro, I., N. Bloom, And X. Lin (2015): "The Finance Uncertainty Mulitplier," Stanford Mimeo.

Ang, A. AND M. PiAzzesi (2003): "A no-arbitrage vector autoregression of term structure dynamics with macroeconomic and latent variables," Journal of Monetary economics, 50, $745-787$.

Arellano, C., Y. Bai, P. J. Kehoe, Et Al. (2012): "Financial frictions and fluctuations in volatility," Federal Reserve Bank of Minneapolis Research Department Staff Report, 466.

Bachmann, R. And C. BAyer (2013): "Wait-and-See' business cycles?" Journal of Monetary Economics, 60, 704-719.

Baker, S. R., N. Bloom, And S. J. Davis (2016): "Measuring Economic Policy Uncertainty," The Quarterly Journal of Economics, 131, 1593-1636.

BASU, S. AND B. BUNDICK (2012): "Uncertainty shocks in a model of effective demand," Tech. rep., National Bureau of Economic Research.

Bekaert, G. And M. Hoerova (2014): "The VIX, the variance premium and stock market volatility," Journal of Econometrics, 183, 181-192.

Berger, D., I. Dew-Becker, And S. Giglio (2017): "Uncertainty shocks as secondmoment news shocks," .

Bernanke, B. (1983): "Irreversibility, Uncertainty and Cyclical Investment," Quarterly Journal of Economics, 98, 85-106.

Bertrand, M. And A. Schoar (2003): "Managing with Style: The Effect of Managers on Firm Policies," The Quarterly Journal of Economics, 118, 1169-1208.

Black, F. And M. Scholes (1973): "The pricing of options and corporate liabilities," Journal of Political Economy, 637-654.

Bloom, N. (2009): "The impact of uncertainty shocks," Econometrica, 77, 623-685. 
Bloom, N., S. Bond, And J. VAn Reenen (2007): "Uncertainty and investment dynamics," Review of Economic Studies, 74, 391-415.

Caballero, R. J., E. M. Engel, J. C. Haltiwanger, M. Woodford, and R. E. HALL (1995): "Plant-level adjustment and aggregate investment dynamics," Brookings papers on economic activity, 1-54.

Caldara, D., C. Fuentes-Albero, S. Gilchrist, And E. Zakrajšek (2016): "The macroeconomic impact of financial and uncertainty shocks," European Economic Review, $88,185-207$.

Christiano, L. J., R. Motto, And M. Rostagno (2014): "Risk Shocks," American Economic Review, 104, 27-65.

Davis, S. J., J. Haltiwanger, And S. Schuh (1996): "Small business and job creation: Dissecting the myth and reassessing the facts," Small Business Economics, 8, 297-315.

Dew-Becker, I., S. Giglio, A. Le, And M. Rodriguez (2015): "The price of variance risk," Tech. rep., National Bureau of Economic Research.

Dixit, A. K. AND R. S. PINDyCK (1994): Investment under uncertainty, Princeton university press.

EGLOFF, D., M. Leippold, And L. Wu (2010): "The term structure of variance swap rates and optimal variance swap investments," Journal of Financial and Quantitative Analysis, $1279-1310$.

Estrella, A. And G. A. Hardouvelis (1991): "The term structure as a predictor of real economic activity," The journal of Finance, 46, 555-576.

Exchange, C. B. O. (2009): "The CBOE volatility index-VIX," White Paper.

Fernández-Villaverde, J., P. Guerrón-Quintana, K. Kuester, and J. RubioRAmírez (2015): "Fiscal Volatility Shocks and Economic Activity," The American Economic Review, 105, 3352-3384. 
Fernández-Villaverde, J., P. Guerrón-Quintana, J. F. Rubio-Ramírez, and M. URiBe (2011): "Risk Matters: The Real Effects of Volatility Shocks," The American Economic Review, 101, 2530-2561.

Gilchrist, S., J. W. Sim, And E. ZakrajŠEK (2014): "Uncertainty, financial frictions, and investment dynamics," Tech. rep., National Bureau of Economic Research.

Gilchrist, S. And J. C. Williams (2005): "Investment, capacity, and uncertainty: a putty-clay approach," Review of Economic Dynamics, 8, 1-27.

Guiso, L. AND G. PARIGi (1999): "Investment and demand uncertainty," Quarterly Journal of Economics, 185-227.

Gulen, H. And M. Ion (2013): "Policy uncertainty and corporate investment," Available at SSRN 2188090.

Gutiérrez, G. and T. Philippon (2016): "Investment-less Growth: An Empirical Investigation," Working Paper 22897, National Bureau of Economic Research.

HARVEy, C. R. (1988): "The real term structure and consumption growth," Journal of Financial Economics, 22, 305-333.

KeHrIG, M. (2011): "The cyclicality of productivity dispersion," US Census Bureau Center for Economic Studies Paper No. CES-WP-11-15.

Knotek II, E. S., S. Khan, Et AL. (2011): "How do households respond to uncertainty shocks?" Economic Review.

Leahy, J. V. And T. M. Whited (1996): "The effect of uncertainty on investment: Some stylized facts," Journal of Money, Credit, and Banking, 28, 64-83.

PINDYCK, R. S. (1990): "Inventories and the short-run dynamics of commodity prices," Tech. rep., National Bureau of Economic Research.

Ramey, G. And V. A. Ramey (1995): "Cross-Country Evidence on the Link Between Volatility and Growth," The American Economic Review, 85, 1138-1151. 
Romer, C. D. (1990): "The great crash and the onset of the Great Depression." Quarterly Journal of Economics, 105.

Stein, L. C. And E. Stone (2013): "The effect of uncertainty on investment, hiring, and r\&d: Causal evidence from equity options," Hiring, and RESD: Causal Evidence from Equity Options (October 4, 2013).

Stock, J. H. And M. W. Watson (2012): "Disentangling the channels of the 2007-09 recession," Brookings Papers on Economic Activity, 120-157. 


\section{A Simulation Appendix}

\section{A.1 Details on Model Solution and Simulation}

We build the simulation model in MATLAB and run it on Stanford's HPC clusters. The firms' dynamic optimization problem is solved using discretization ${ }^{12}$ and a standard policy iteration algorithm, which we illustrate below. First we make an initial guess $V_{0}\left(A, k, l, \sigma_{s}, \sigma_{l}\right)$ for the value function and find initial optimal policies $k_{1}\left(A, k, l, \sigma_{s}, \sigma_{l}\right)$ and $l_{1}\left(A, k, l, \sigma_{s}, \sigma_{l}\right)$ to maximize the firm's current revenue and expected continuation value under the assumption that the value function is $V_{0}$. Then we obtain the next guess for the value function, $V_{1}$, as the value that would arise from following policies $k_{1}$ and $l_{1}$. In practice we approximate $V_{1}$ by iterating on our current guess of the policies 300 times. That is we define

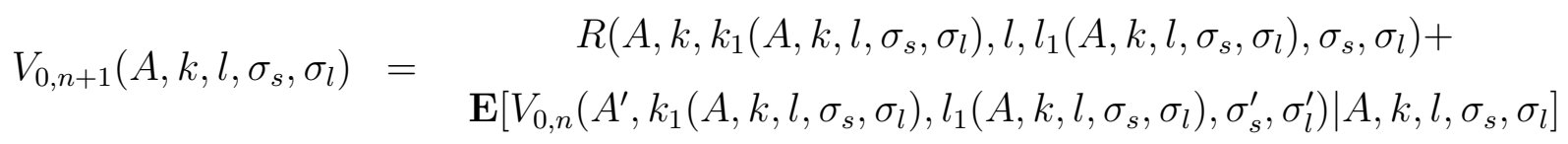

where $R(\cdot)$ denotes the flow returns function containing revenues minus investment and hiring costs, and $\mathbf{E}[\cdot]$ is the conditional expectations operator based on the current state $\left(A, k, l, \sigma_{s}, \sigma_{l}\right)$, and let $V_{1}=V_{0,300}$. We then obtain our second guesses for the policy functions $k_{2}$ and $l_{2}$ via maximization under the new guess $V_{1}$ and take the absolute distance $d=$ $\max _{A, k, l, \sigma_{s}, \sigma_{l}}\left|k_{2}-k_{1}\right|$. If $d$ is below a pre-determined tolerance level, we conclude that $V_{1}$, $k_{2}$, and $l_{2}$ solve the firm's dynamic program. Otherwise, we repeat the above procedure by iterating on policy functions $k_{2}$ and $l_{2}$ to obtain $V_{2}=V_{1,300}$ and new candidate policy functions $k_{3}$ and $l_{3}$. The algorithm continues until convergence, which comes a lot faster under this procedure than with standard value function iteration, as is well known in the computational literature.

To simulate data from the model we use Monte Carlo simulation, in order to accommodate the fact that the firms in our simulation dataset consist of 25 investment units, each making optimal investments according to the value function problem formulated in section

\footnotetext{
${ }^{12}$ We use full discretization of the state space to accommodate the "sharp" adjustment costs in the model, which may lead the value function to be non-differentiable in certain regions of the state space. Similarly, we refrain from using interpolation at any point during the solution procedure to avoid interpolating within these regions of non-differentiability.
} 
5. The investment units within a firm have independent first-moment shocks but common uncertainty shocks. For each firm-month in the simulation, we first obtain $\sigma_{s}$ and $\sigma_{l}$ states for the firm, then draw new first-moment shocks $A$ for all of the units within the firm, then record investment and hiring choices by unit. Finally, we aggregate the unit-level data to the firm level by adding up $K$ and $L$ across units within a firm-month. We run the simulation for 360 months, dropping data from the first 300 months for ergodicity.

We transfer the simulated data to Stata, where we aggregate the monthly simulation data to quarterly and annual frequencies and run the empirical analysis of the simulated data, as described in the main text.

\section{A.2 Simulation Parameters}

Appendix Table 1 displays the parameters used in the baseline calibration for the two-factor model with capital and labor. We discuss most of our choices in Section 5.2, and list sources as appropriate in the parameterization tables.

\section{B Data Appendix}

\section{B.1 Construction of the Firm-level Implied Volatility Dataset}

We obtain our implied volatility data from the OptionMetrics database. OptionMetrics uses observed option trading data to provide information about theoretical "standardized" options, which are theoretical American put and call options with strike prices equal to atthe-money forward stock prices and fixed maturities of 30,60, 91, 152, 182, 273, 365, and 730 days. They obtain these standardized options by using all available options on the same security and weighting them by vega, maturity, delta, and exercise style. They generate a volatility surface using a normal kernel weighting function and choosing bandwidth empirically, and calculate standardized option prices and implied volatilities from this surface. Details of this procedure are available at http://www.optionmetrics.com/. Options must have vegas greater than 0.5 and time to maturity greater than 10 days to be input into the standardization process. Note these are integrated volatilities rather than spot volatilities - 
so for example $\sigma_{6-\text { month }}^{2}=\int_{0}^{6-\text { months }} \sigma_{t}^{2} d t$ and cited in annualized units. An observation in the raw data is a firm-day.

To construct the implied volatility dataset we first obtain a single measure of implied volatility for each horizon by firm-day by averaging implied volatility across puts and calls. Put and call data are nearly identical, with correlations close to .99, so using either puts or calls made little difference to the empirical results. Then we compute quarterly measures of implied volatility by horizon by averaging the daily implied variance of the standardized options $^{13}$. That is, the implied volatility of a firm $i$ during quarter $t$ is $\sigma_{i t}=\sqrt{\frac{1}{N_{t}} \sum_{\tau=1}^{N_{t}} s_{i \tau}^{2}}$ where $s_{i \tau}$ is a daily observation of implied volatility for the firm and $N_{t}$ is the number of days in quarter $t$ for which we have nonmissing volatility observations. Our empirical specifications in exploit variation in the level and slope of firm-specific volatility curves. These curves plot a firm's implied volatility by horizon, and thus capture the degree of uncertainty the firm faces in the short and long run.

\section{B.2 Matching Implied Volatility Data to Compustat}

We match the quarterly dataset to quarterly and annual firm-level data from Compustat North America. In constructing the annual matched dataset we take the implied volatility for a firm-year to be that of the last quarter of the year. This is useful to obtain less noisy implied volatility measures at an annual frequency and allows us to exploit the forwardlooking nature of implied volatility. Since many of our regressions in section 4 use lagged volatility, we effectively regress an annual outcome variable on the implied volatility in final months of the previous fiscal year, which reflects the market's uncertainty about the firm looking forward to the year in question. For the quarterly matched dataset we simply match by quarter.

See Appendix Table 2 for summary statistics on the samples defined by the baseline regressions in Table 3 .

Selection into our matched sample is largely based on the availability of accounting data from Compustat and implied volatility data from OptionMetrics, specifically selecting firms with options of durations of at least six months. We test for selection into this sample in

\footnotetext{
${ }^{13}$ We use a monthly average for the drivers exercise from Section 3 , with the results in Table 2
} 
Appendix Table 3, where we run linear probability models to predict whether a Compustat firm has non-missing 30-day and 6-month implied volatility in a particular month. This exercise suggests that larger, faster growing, and less volatile firms are more likely to have non-missing implied volatility data at both horizons.

\section{B.3 Additional Details on Testing for Drivers of Short- and Long- run Uncertainty}

See section 3 for an outline of how we construct the matched firm-quarter dataset containing implied volatility and drivers data.

During our estimation of the sector-level sensitivities of equity returns to market, oil, and currency returns we restrict attention to SIC-2 sectors that featured at least 20 distinct firms during the estimation period of 1985-2004. When we restricted attention to sectors that included 15 or 25 firms the results did not change very much.

All of our uncertainty regressions in Table 2 are weighted by employment, as is standard in this line of literature (e.g. Baker et al., 2016). Also following Baker et al. (2016) whenever we have the firm-specific economic policy uncertainty index as a regressor we include a control consisting of federal spending as a fraction of GDP multiplied by firm-level exposure to government purchases.

In our baseline regressions in in Table 2 we define CEO turnover as an indicator for firmquarters during which Execucomp records a CEO stepping down. In the data, only $78 \%$ of these CEO departures have a new CEO taking office within the same calendar quarter, but our regressions are robust to defining CEO turnover as an indicator for firm-quarters with a new CEO coming in. The same is true if we define turnover to indicate any change in the identity of the CEO within the quarter, regardless of whether the CEO is replaced during the quarter, the post becomes vacant and is unfilled within the calendar quarter, or a new CEO takes over a vacancy that began in a previous quarter. 


\section{Table 1: Predicting Long-run Implied Volatility}

\begin{tabular}{lccccc}
\hline \hline & $(1)$ & $(2)$ & $(3)$ & $(4)$ & $(5)$ \\
Dependent Variable & $\begin{array}{c}\text { 2-year } \\
\text { Firm } \\
\text { Implied } \\
\text { Vol. }\end{array}$ & 1-year VIX & 2-year VIX & 3-year VIX & 5-year VIX \\
& & & & & \\
\hline \multirow{3}{*}{ 30-day Volatility } & $0.869^{* * *}$ & $0.942^{* * *}$ & $0.866^{* * *}$ & $0.818^{* * *}$ & $0.735^{* * *}$ \\
& $(0.00583)$ & $(0.0115)$ & $(0.0266)$ & $(0.0332)$ & $(0.0469)$ \\
6-month - 30-day & & & & & \\
Volatility & $1.162^{* * *}$ & $1.233^{* * *}$ & $1.347^{* * *}$ & $1.369^{* * *}$ & $1.336^{* * *}$ \\
& $(0.0385)$ & $(0.0330)$ & $(0.0733)$ & $(0.0917)$ & $(0.125)$ \\
Constant & $4.455^{* * *}$ & $1.423^{* * *}$ & $3.522^{* * *}$ & $5.067 * * *$ & $7.844^{* * *}$ \\
& $(0.194)$ & $(0.303)$ & $(0.689)$ & $(0.842)$ & $(1.139)$ \\
& & & & & \\
Observations & 20,999 & 3,585 & 3,585 & 3,585 & 3,585 \\
R-squared & 0.946 & 0.993 & 0.971 & 0.949 & 0.901 \\
\hline \hline
\end{tabular}

Notes: Column (1) regresses quarterly firm-level 2-year implied volatility (source: Optionmetrics) on 30-day and 6-month minus 30-day implied volatility. Columns (2) to (6) regress the daily generalized VIX for the specified horizon on the contemporaneous 30-day and 6-month minus 30day generalized VIX (source: Goldman Sachs). Column (1) standard errors clustered by firm. Columns (2) to (6) report Newey-West standard errors, assuming autocorrelation up to 250 trading days. $* * * \mathrm{p}<0.01, * * \mathrm{p}<0.05, * \mathrm{p}<0.1$ 
Table 2: Drivers of Short- and Long-run Uncertainty (Monthly Freq.)

(1)

Dependent Variable

Economic Policy Unc. Exposure

0.072

$(0.057)$

Oil Vol. Exposure

Currency Vol. Exposure

CEO Turnover
(2)

(3)

$\log (30 d$ IVOL)
(5)

(4)

$\begin{array}{ccc} & & \\ & & 0.071 \\ & & (0.057) \\ & & 0.451^{*} \\ & & (0.240) \\ & & 0.068 \\ 0.069 & & (0.072) \\ (0.072) & & 0.035^{* * *} \\ & 0.035^{* * *} & (0.012)\end{array}$

Dependent Variable

Economic Policy Unc. Exposure

$0.102^{*}$

(0.061)

Oil Vol. Exposure

Currency Vol. Exposure

CEO Turnover $\log (6 \mathrm{~m}$ IVOL $)$

$$
0.430^{*}
$$

(0.012)

(0.012)

$(0.057)$

0.068

$0.072)$ 
Table 3: Investment, R\&D Activity, and Hiring under Short- and Long-run Uncertainty (OLS)

\begin{tabular}{|c|c|c|c|c|c|c|}
\hline Dependent Variable & $\begin{array}{c}\text { (1) } \\
\text { Investment }\end{array}$ & $\begin{array}{c}(2) \\
\text { R\&D } \\
\text { Growth }\end{array}$ & $\begin{array}{c}(3) \\
\text { R\&D } \\
\text { Growth - } \\
\text { Investment }\end{array}$ & $\begin{array}{c}\text { (4) } \\
\text { Investment }\end{array}$ & $\begin{array}{c}(5) \\
\text { Hiring }\end{array}$ & $\begin{array}{c}(6) \\
\text { Investment } \\
\text { - Hiring }\end{array}$ \\
\hline Frequency & $\mathbf{Q}$ & $\mathbf{Q}$ & $\mathbf{Q}$ & $\mathbf{A}$ & A & $\mathbf{A}$ \\
\hline Lag $\log (30 d$ IVOL) & $\begin{array}{c}-0.114 * * * \\
(0.044)\end{array}$ & $\begin{array}{c}-0.058 * * \\
(0.027)\end{array}$ & $\begin{array}{c}0.009 \\
(0.060)\end{array}$ & $\begin{array}{c}-0.154 * * * \\
(0.042)\end{array}$ & $\begin{array}{l}-0.015 \\
(0.014)\end{array}$ & $\begin{array}{c}-0.139 * * * \\
(0.043)\end{array}$ \\
\hline Lag $\log (6 \mathrm{~m}$ IVOL $)-\log (30 \mathrm{~d}$ IVOL) & $\begin{array}{l}-0.048 \\
(0.087)\end{array}$ & $\begin{array}{c}-0.416^{* *} \\
(0.183)\end{array}$ & $\begin{array}{l}-0.418^{*} \\
(0.215)\end{array}$ & $\begin{array}{c}-0.390 * * * \\
(0.114)\end{array}$ & $\begin{array}{c}-0.125 * * * \\
(0.043)\end{array}$ & $\begin{array}{c}-0.265^{* *} \\
(0.108)\end{array}$ \\
\hline Lag Tobin's Q & $\begin{array}{c}0.112 * * * \\
(0.012)\end{array}$ & $\begin{array}{c}0.006 \\
(0.006)\end{array}$ & $\begin{array}{c}-0.107 * * * \\
(0.011)\end{array}$ & $\begin{array}{c}0.106 * * * \\
(0.013)\end{array}$ & $\begin{array}{c}0.012 * * * \\
(0.003)\end{array}$ & $\begin{array}{c}0.094 * * * \\
(0.011)\end{array}$ \\
\hline Cash Flow / Assets & $\begin{array}{c}1.241 * * * \\
(0.193)\end{array}$ & $\begin{array}{c}1.464 \\
(1.317)\end{array}$ & $\begin{array}{c}0.451 \\
(1.169)\end{array}$ & $\begin{array}{c}0.749 * * * \\
(0.150)\end{array}$ & $\begin{array}{c}0.215^{* * * *} \\
(0.055)\end{array}$ & $\begin{array}{c}0.533 * * * \\
(0.141)\end{array}$ \\
\hline Sales Growth & $\begin{array}{c}0.310^{* * * *} \\
(0.036)\end{array}$ & $\begin{array}{c}0.002 \\
(0.021)\end{array}$ & $\begin{array}{c}-0.287 * * * \\
(0.054)\end{array}$ & $\begin{array}{c}0.513 * * * \\
(0.047)\end{array}$ & $\begin{array}{c}0.399 * * * \\
(0.024)\end{array}$ & $\begin{array}{c}0.114 * * * \\
(0.038)\end{array}$ \\
\hline Observations & 103,900 & 68,729 & 67,511 & 25,199 & 25,224 & 25,199 \\
\hline R-squared & 0.578 & 0.210 & 0.288 & 0.685 & 0.399 & 0.660 \\
\hline Clusters & 4775 & 3167 & 3152 & 4194 & 4195 & 4194 \\
\hline
\end{tabular}

Notes: Regressions are quarterly (Q) in columns (1) to (3) and annual (A) in columns (4) to (6). All columns include a full set of firm and date fixed effects and are weighted by quarterly or annual sales, respectively. Robust standard errors in parentheses, clustered by firm. Data is from Compustat for accounting variables matched to data on implied volatility of standardized options taken from OptionMetrics. Investment is measured as the log of capital expenditure (CAPEX) over lagged net plant property and equipment (PPENT). R\&D growth is measured as the change across periods in R\&D expense (XRD) divided by the average, and imputed to zero if both current and lagged values are both zero. R\&D expense is imputed to zero if missing but the firm previously reported positive R\&D expense. Hiring is measured as the change in the stock of employees across fiscal years, divided by the average between the current and previous year. Tobin's $Q$ is measured as the sum of market value, preferred stock capital, current and long-term liabilities, all divided by the book value of assets. Cash flow is defined as operating income. In annual specifications, the implied volatility for a given fiscal year is taken to be the average implied volatility during the last quarter of the year, while it is taken as the average for the quarter in quarterly specifications. In the regressions, implied volatility is lagged by 1 or 4 quarters depending on whether the frequency is quarterly or annual. All variables are winsorized at the 1st and 99th percentiles. $* * * \mathrm{p}<0.01, * * \mathrm{p}<0.05, * \mathrm{p}<0.1$ 


\section{Table 4: Investment, R\&D Activity, and Hiring under Short- and Long-run Uncertainty}

(IV)

\begin{tabular}{|c|c|c|c|c|c|c|}
\hline Dependent Variable & $\begin{array}{c}(1) \\
\text { Investment }\end{array}$ & $\begin{array}{c}(2) \\
\text { R\&D } \\
\text { Growth }\end{array}$ & $\begin{array}{c}(3) \\
\text { R\&D } \\
\text { Growth - } \\
\text { Investment }\end{array}$ & $\begin{array}{c}\text { (4) } \\
\text { Investment }\end{array}$ & $\begin{array}{c}(5) \\
\text { Hiring }\end{array}$ & $\begin{array}{c}(6) \\
\text { Investment - } \\
\text { Hiring }\end{array}$ \\
\hline Frequency & $\mathbf{Q}$ & $\mathbf{Q}$ & $\mathbf{Q}$ & $\mathbf{A}$ & A & A \\
\hline $\log (30 \mathrm{~d}$ IVOL $)$ & $\begin{array}{l}-1.158^{*} \\
(0.641)\end{array}$ & $\begin{array}{l}-0.827 \\
(1.507)\end{array}$ & $\begin{array}{c}0.676 \\
(1.127)\end{array}$ & $\begin{array}{l}-1.117 \\
(0.778)\end{array}$ & $\begin{array}{c}-0.409 * * \\
(0.181)\end{array}$ & $\begin{array}{l}-0.926 \\
(0.705)\end{array}$ \\
\hline $\log (6 \mathrm{~m}$ IVOL $)-\log (30 \mathrm{~d}$ IVOL $)$ & $\begin{array}{c}-6.076^{* *} \\
(2.497)\end{array}$ & $\begin{array}{c}-18.428 * \\
(9.419)\end{array}$ & $\begin{array}{l}-9.195 \\
(7.577)\end{array}$ & $\begin{array}{l}-5.277 \\
(3.656)\end{array}$ & $\begin{array}{c}-2.699^{*} \\
(1.413)\end{array}$ & $\begin{array}{l}-3.045 \\
(2.824)\end{array}$ \\
\hline Lag Tobin's Q & $\begin{array}{c}0.176^{* * * *} \\
(0.021)\end{array}$ & $\begin{array}{l}0.105^{*} \\
(0.061)\end{array}$ & $\begin{array}{l}-0.077 * \\
(0.043)\end{array}$ & $\begin{array}{c}0.184 * * * \\
(0.034)\end{array}$ & $\begin{array}{c}0.041 * * \\
(0.016)\end{array}$ & $\begin{array}{c}0.146 * * * \\
(0.028)\end{array}$ \\
\hline Exposure to Federal Spending & $\begin{array}{c}10.485 \\
(37.535)\end{array}$ & $\begin{array}{c}-161.835^{*} \\
(88.780)\end{array}$ & $\begin{array}{c}-152.814 * * \\
(69.565)\end{array}$ & $\begin{array}{c}36.014 \\
(45.807)\end{array}$ & $\begin{array}{c}-1.594 \\
(10.952)\end{array}$ & $\begin{array}{c}44.299 \\
(42.585)\end{array}$ \\
\hline Cash Flow / Assets & $\begin{array}{c}0.710^{* * *} \\
(0.341)\end{array}$ & $\begin{array}{c}0.285 \\
(2.758)\end{array}$ & $\begin{array}{l}-0.121 \\
(2.289)\end{array}$ & $\begin{array}{c}0.733 * * \\
(0.279)\end{array}$ & $\begin{array}{l}0.151^{*} \\
(0.085)\end{array}$ & $\begin{array}{l}0.568^{* *} \\
(0.273)\end{array}$ \\
\hline Sales Growth & $\begin{array}{c}0.215^{* * *} \\
(0.078)\end{array}$ & $\begin{array}{c}0.120 \\
(0.204)\end{array}$ & $\begin{array}{l}-0.109 \\
(0.150)\end{array}$ & $\begin{array}{c}0.740^{* *} \\
(0.282)\end{array}$ & $\begin{array}{c}0.691 * * * \\
(0.141)\end{array}$ & $\begin{array}{c}0.034 \\
(0.203)\end{array}$ \\
\hline Observations & 47,452 & 31,010 & 30,757 & 12,578 & 10,988 & 10,968 \\
\hline Clusters & 60 & 53 & 53 & 59 & 59 & 59 \\
\hline F-stat (Cragg-Donald) & 23.806 & 29.407 & 31.473 & 17.696 & 15.931 & 16.058 \\
\hline F-stat (Kleinberger-Paap) & 4.349 & 4.975 & 5.421 & 3.848 & 3.770 & 3.874 \\
\hline Hansen J p-val & 0.111 & 0.324 & 0.836 & 0.352 & 0.0869 & 0.734 \\
\hline
\end{tabular}

Notes: Columns (1) to (3) are quarterly (Q), (4) to (6) are annual (A) and all include a full set of firm and date fixed effects, and are weighted by quarterly or annual sales, respectively. Robust standard errors in parentheses, clustered by SIC-2 sector. Data is from Compustat for accounting variables, matched to data on implied volatility of standardized options taken from OptionMetrics. Investment is the log of capital expenditure (CAPEX) over lagged net plant property and equipment (PPENT). R\&D growth is measured as the change across periods in R\&D expense (XRD), divided by the average between the two. R\&D expense is taken to be zero if missing but the firm previously reported positive R\&D expense. Tobin's $\mathrm{Q}$ is measured as the sum of market value, preferred stock capital, current and long-term liabilities all divided by the book value of assets. Cash flow is operating income. Exposure to federal spending is from Baker et al (2016), constructed as the interaction between a firm-specific dependence on government purchases (based on line-of-business data) and federal spending as a ratio of GDP. Volatility (uncertainty) variables treated as endogenous, with instruments including firm-level exposure to economic policy uncertainty (from Baker et al, 2016), and exposure to oil and currency volatility by SIC-2 sector. . Implied volatility is measured as the average for the quarter in quarterly specifications, and as the average for the year in the annual specifications. All variables are winsorized at the 1st and 99th percentiles. $* * * \mathrm{p}<0.01, * * \mathrm{p}<0.05, * \mathrm{p}<0.1$ 
Table 5: Leverage and the Time Profile of Uncertainty

\begin{tabular}{|c|c|c|c|c|c|c|c|c|c|}
\hline & (1) & (2) & (3) & (4) & $(5)$ & (6) & (7) & $(8)$ & (9) \\
\hline Dependent Variable & \multicolumn{3}{|c|}{ Investment } & \multicolumn{3}{|c|}{ R\&D Growth } & \multicolumn{3}{|c|}{ Hiring } \\
\hline Sample & All & $\begin{array}{c}\text { Low } \\
\text { leverage }\end{array}$ & $\begin{array}{c}\text { High } \\
\text { leverage }\end{array}$ & All & $\begin{array}{c}\text { Low } \\
\text { leverage }\end{array}$ & $\begin{array}{c}\text { High } \\
\text { leverage }\end{array}$ & All & $\begin{array}{c}\text { Low } \\
\text { leverage }\end{array}$ & $\begin{array}{c}\text { High } \\
\text { leverage }\end{array}$ \\
\hline Frequency & $\mathbf{Q}$ & $\mathbf{Q}$ & $\mathbf{Q}$ & $\mathbf{Q}$ & $\mathbf{Q}$ & $\mathbf{Q}$ & $\mathbf{A}$ & $\mathbf{A}$ & $\mathbf{A}$ \\
\hline Lag $\log (30 d$ IVOL $)$ & $\begin{array}{c}-0.114 * * * \\
(0.044)\end{array}$ & $\begin{array}{c}0.127 \\
(0.078)\end{array}$ & $\begin{array}{c}-0.167 * * * \\
(0.045)\end{array}$ & $\begin{array}{c}-0.058 * * \\
(0.027)\end{array}$ & $\begin{array}{l}-0.022 \\
(0.071)\end{array}$ & $\begin{array}{l}-0.078 \\
(0.048)\end{array}$ & $\begin{array}{l}-0.015 \\
(0.014)\end{array}$ & $\begin{array}{c}0.019 \\
(0.016)\end{array}$ & $\begin{array}{l}-0.035^{*} \\
(0.019)\end{array}$ \\
\hline $\begin{array}{l}\text { Lag } \log (6 m \text { IVOL })-\log (30 d \\
\text { IVOL })\end{array}$ & $\begin{array}{l}-0.048 \\
(0.087)\end{array}$ & $\begin{array}{c}0.251 \\
(0.166)\end{array}$ & $\begin{array}{l}-0.136 \\
(0.098)\end{array}$ & $\begin{array}{c}-0.416^{* *} \\
(0.183)\end{array}$ & $\begin{array}{l}-0.066 \\
(0.250)\end{array}$ & $\begin{array}{c}-0.581 * * \\
(0.258)\end{array}$ & $\begin{array}{c}-0.125^{* * *} \\
(0.043)\end{array}$ & $\begin{array}{l}-0.060 \\
(0.061)\end{array}$ & $\begin{array}{c}-0.164 * * * \\
(0.056)\end{array}$ \\
\hline Lag Tobin's Q & $\begin{array}{c}0.112 * * * \\
(0.012)\end{array}$ & $\begin{array}{c}0.099 * * * \\
(0.014)\end{array}$ & $\begin{array}{c}0.163 * * * \\
(0.022)\end{array}$ & $\begin{array}{c}0.006 \\
(0.006)\end{array}$ & $\begin{array}{c}0.009 \\
(0.009)\end{array}$ & $\begin{array}{c}0.003 \\
(0.009)\end{array}$ & $\begin{array}{c}0.012 * * * \\
(0.003)\end{array}$ & $\begin{array}{c}0.010^{* *} \\
(0.004)\end{array}$ & $\begin{array}{c}0.021 * * * \\
(0.006)\end{array}$ \\
\hline Cash Flow / Assets & $\begin{array}{c}1.241 * * * \\
(0.193)\end{array}$ & $\begin{array}{c}0.921 * * * \\
(0.213)\end{array}$ & $\begin{array}{c}1.298 * * * \\
(0.279)\end{array}$ & $\begin{array}{c}1.464 \\
(1.317)\end{array}$ & $\begin{array}{c}0.112 \\
(1.945)\end{array}$ & $\begin{array}{l}2.592 * \\
(1.534)\end{array}$ & $\begin{array}{c}0.215^{* * *} * \\
(0.055)\end{array}$ & $\begin{array}{c}0.198 * * * \\
(0.069)\end{array}$ & $\begin{array}{c}0.295 * * * \\
(0.082)\end{array}$ \\
\hline Sales Growth & $\begin{array}{c}0.310 * * * \\
(0.036)\end{array}$ & $\begin{array}{c}0.254 * * * \\
(0.073)\end{array}$ & $\begin{array}{c}0.280 * * * \\
(0.040)\end{array}$ & $\begin{array}{c}0.002 \\
(0.021)\end{array}$ & $\begin{array}{c}0.044 \\
(0.049)\end{array}$ & $\begin{array}{l}-0.033 \\
(0.028)\end{array}$ & $\begin{array}{c}0.399 * * * \\
(0.024)\end{array}$ & $\begin{array}{c}0.318 * * * \\
(0.039)\end{array}$ & $\begin{array}{c}0.430 * * * \\
(0.030)\end{array}$ \\
\hline Observations & 103,900 & 51,236 & 51,575 & 68,729 & 38,556 & 29,873 & 25,224 & 12,571 & 12,601 \\
\hline R-squared & 0.578 & 0.600 & 0.588 & 0.210 & 0.223 & 0.221 & 0.399 & 0.476 & 0.432 \\
\hline Firms & 4775 & 3359 & 3028 & 3167 & 2440 & 1825 & 4195 & 2821 & 2602 \\
\hline
\end{tabular}

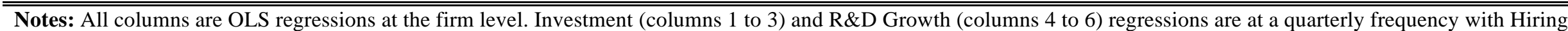

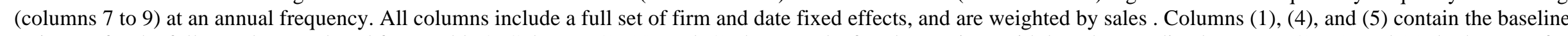

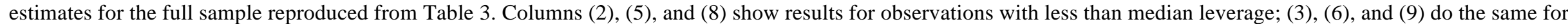

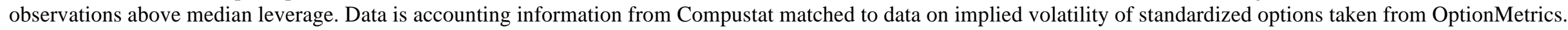

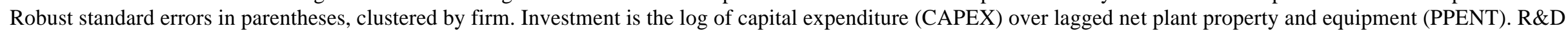

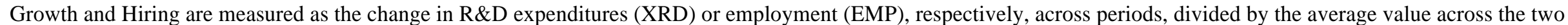

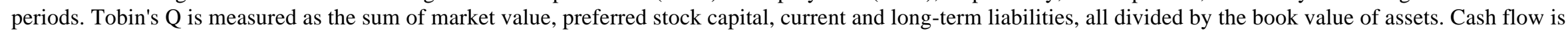

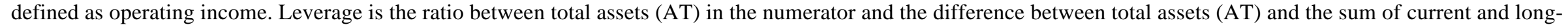

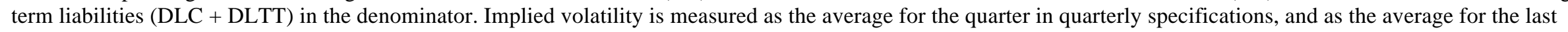
quarter of the fiscal year in the annual specifications. All variables are winsorized at the 1 st and 99 th percentiles. $* * * \mathrm{p}<0.01, * * \mathrm{p}<0.05, * \mathrm{p}<0.1$ 
Table 6: Investment Under Short- and Long-run Uncertainty, Robustness

\begin{tabular}{|c|c|c|c|c|c|c|c|c|}
\hline & (1) & (2) & (3) & (4) & $(5)$ & $(6)$ & (7) & (8) \\
\hline Dependent Variable & \multicolumn{8}{|c|}{ Investment } \\
\hline Estimator & OLS & OLS & OLS & OLS & IV & IV & IV & IV \\
\hline Specification & Baseline & $\begin{array}{c}\text { Lagged } \\
\text { Investment }\end{array}$ & 1-year IVOL & $\begin{array}{l}\text { 2-year } \\
\text { IVOL }\end{array}$ & Baseline & $\begin{array}{c}\text { Lagged } \\
\text { Investment }\end{array}$ & $\begin{array}{l}\text { 1-year } \\
\text { IVOL }\end{array}$ & $\begin{array}{l}\text { 2-year } \\
\text { IVOL }\end{array}$ \\
\hline $\log (30 \mathrm{~d}$ IVOL $)$ & $\begin{array}{c}-0.114 * * * \\
(0.044)\end{array}$ & $\begin{array}{c}-0.078 * * * \\
(0.025)\end{array}$ & $\begin{array}{c}-0.151 * * \\
(0.073)\end{array}$ & $\begin{array}{l}-0.124^{*} \\
(0.070)\end{array}$ & $\begin{array}{c}-1.158 * \\
(0.641)\end{array}$ & $\begin{array}{l}-0.829 * \\
(0.455)\end{array}$ & $\begin{array}{c}-1.276^{* *} \\
(0.533)\end{array}$ & $\begin{array}{c}-1.359 * * \\
(0.662)\end{array}$ \\
\hline $\log (6 \mathrm{~m}$ IVOL $)-\log (30 \mathrm{~d}$ IVOL $)$ & $\begin{array}{l}-0.048 \\
(0.087)\end{array}$ & $\begin{array}{l}-0.098 \\
(0.063)\end{array}$ & & & $\begin{array}{c}-6.076 * * \\
(2.497)\end{array}$ & $\begin{array}{c}-5.232 * * \\
(1.978)\end{array}$ & & \\
\hline $\log (1 \mathrm{y}$ IVOL $)-\log (30 \mathrm{~d}$ IVOL $)$ & & & $\begin{array}{l}-0.153 \\
(0.119)\end{array}$ & & & & $\begin{array}{c}-3.774 * * * \\
(1.160)\end{array}$ & \\
\hline $\log (2 y$ IVOL $)-\log (30 d$ IVOL $)$ & & & & $\begin{array}{l}-0.127 \\
(0.097)\end{array}$ & & & & $\begin{array}{c}-3.547 * * \\
(1.352)\end{array}$ \\
\hline Lag Investment & & $\begin{array}{c}0.402 * * * \\
(0.019)\end{array}$ & & & & $\begin{array}{c}0.347 * * * \\
(0.038)\end{array}$ & & \\
\hline Lag Tobin's Q & $\begin{array}{c}0.112 * * * \\
(0.012)\end{array}$ & $\begin{array}{c}0.072 * * * \\
(0.007)\end{array}$ & $\begin{array}{c}0.106 * * * \\
(0.015)\end{array}$ & $\begin{array}{c}0.098 * * * \\
(0.015)\end{array}$ & $\begin{array}{c}0.176^{* * * *} \\
(0.021)\end{array}$ & $\begin{array}{c}0.131 * * * \\
(0.018)\end{array}$ & $\begin{array}{c}0.159 * * * \\
(0.017)\end{array}$ & $\begin{array}{c}0.143 * * * \\
(0.020)\end{array}$ \\
\hline Exposure to Federal Spending & & & & & $\begin{array}{c}10.485 \\
(37.535)\end{array}$ & $\begin{array}{c}-4.014 \\
(27.461)\end{array}$ & $\begin{array}{c}28.568 \\
(38.559)\end{array}$ & $\begin{array}{c}69.101 \\
(56.511)\end{array}$ \\
\hline Cash Flow / Assets & $\begin{array}{c}1.241^{* * * *} \\
(0.193)\end{array}$ & $\begin{array}{c}1.414 * * * \\
(0.215)\end{array}$ & $\begin{array}{c}1.249 * * * \\
(0.306)\end{array}$ & $\begin{array}{c}1.321 * * * \\
(0.309)\end{array}$ & $\begin{array}{c}0.710 * * \\
(0.341)\end{array}$ & $\begin{array}{c}0.890 * * \\
(0.388)\end{array}$ & $\begin{array}{c}0.657 \\
(0.416)\end{array}$ & $\begin{array}{l}0.985 * \\
(0.513)\end{array}$ \\
\hline Sales Growth & $\begin{array}{c}0.310 * * * \\
(0.036) \\
\end{array}$ & $\begin{array}{c}0.199 * * * \\
(0.025)\end{array}$ & $\begin{array}{c}0.280 * * * \\
(0.050)\end{array}$ & $\begin{array}{c}0.341 * * * \\
(0.054)\end{array}$ & $\begin{array}{c}0.215^{* * *} * \\
(0.078)\end{array}$ & $\begin{array}{c}0.152 * * \\
(0.061)\end{array}$ & $\begin{array}{c}0.192 * * \\
(0.088) \\
\end{array}$ & $\begin{array}{l}0.231 * \\
(0.121) \\
\end{array}$ \\
\hline Observations & 103,900 & 95,998 & 28,771 & 20,722 & 47,452 & 45,110 & 17,285 & 11,006 \\
\hline Clusters & 4775 & 4498 & 1504 & 1363 & 60 & 60 & 57 & 56 \\
\hline R-squared & 0.578 & 0.658 & 0.621 & 0.631 & 0.475 & 0.562 & 0.600 & 0.563 \\
\hline F-stat (Cragg-Donald) & & & & & 23.806 & 22.364 & 28.344 & 23.622 \\
\hline F-stat (Kleinberger-Paap) & & & & & 4.349 & 3.589 & 2.312 & 2.881 \\
\hline Hansen J p-value & & & & & 0.216 & 0.226 & 0.389 & 0.513 \\
\hline
\end{tabular}

Notes: All columns are quarterly regressions weighted by sales and include a full set of firm and date fixed effects. Columns (1) to (4) are OLS regressions and (5) to (8) are 2SLS instrumental variables regressions. Robust standard errors in parentheses, clustered by firm in columns (1) to (4), by 2-digit SIC in (5) to (8). Data is from Compustat for accounting variables matched to data on implied volatility of standardized options taken from OptionMetrics. Investment is measured as the log of capital expenditure (CAPEX) over lagged net plant, property, and equipment (PPENT). Tobin's Q is measured as the sum of market value, preferred stock capital, current, and long-term liabilities, all divided by the book value of assets. Cash flow is defined as operating income. Exposure to federal spending is from Baker et al (2016), constructed as the interaction between a firm-specific dependence on government purchases (based on line-of-business data) and the ratio of federal spending to GDP. Volatility variables are treated as endogenous in columns (5) to (8) with excluded instruments including firm-level exposure to economic policy uncertainty (from Baker et al, 2016), and exposure to oil and currency volatility by SIC-2 sector. Implied volatilities measured as the average for the quarter and lagged for the OLS specifications in columns $(1)$ to $(4)$. $* * *$ p $<0.01$, $* *$ $\mathrm{p}<0.05, * \mathrm{p}<0.1$ 


\section{Table 7: Simulation Quarterly Capital Investment Under Short- and Long-run Uncertainty}

(1)

Dependent Variable

Lag $\log (30 \mathrm{~d}$ Expected Vol.) $\quad-0.053 * * *$

$(0.004)$

Lag $\log (2 \mathrm{y}$ Expected Vol.)

Lag $\log (2 \mathrm{y}$ Expected Vol.) $\log$ (30d Expected Vol.)

Lag $\log (6 \mathrm{~m}$ Expected Vol.) $\log (30 \mathrm{~d}$ Expected Vol.)

Lag Tobin's Q

Cash Flow/(K+L)

Sales Growth
Lag $\log (6 \mathrm{~m}$ Expected Vol.)
(2)

(3)

(4)

(5)

(6)

Net Investment
(7)

$\begin{array}{cccc}-0.217 * * * & -0.114 * * * & -0.211^{* * *} & -0.125 * * * \\ (0.022) & (0.009) & (0.020) & (0.008)\end{array}$

$-0.205 * * *$

$(0.013)$

$$
-0.091 * * *
$$

(0.006)

\begin{tabular}{|c|c|c|c|c|c|c|c|}
\hline $\begin{array}{l}\text { Lag } \log (2 \text { y Expected Vol.) - } \\
\quad \log (30 \text { d Expected Vol.) }\end{array}$ & & & & $\begin{array}{c}-0.223 * * * \\
(0.029)\end{array}$ & & $\begin{array}{c}-0.193 * * * \\
(0.026)\end{array}$ & \\
\hline $\begin{array}{l}\text { Lag } \log (6 \mathrm{~m} \text { Expected Vol. })- \\
\log (30 \mathrm{~d} \text { Expected Vol. })\end{array}$ & & & & & $\begin{array}{c}-0.164 * * * \\
(0.020)\end{array}$ & & $\begin{array}{c}-0.153^{* * *} \\
(0.019)\end{array}$ \\
\hline Lag Tobin's Q & $\begin{array}{c}0.079 * * * \\
(0.001)\end{array}$ & $\begin{array}{c}0.079 * * * \\
(0.001)\end{array}$ & $\begin{array}{c}0.079 * * * \\
(0.001)\end{array}$ & $\begin{array}{c}0.079 * * * \\
(0.001)\end{array}$ & $\begin{array}{c}0.079 * * * \\
(0.001)\end{array}$ & $\begin{array}{c}0.044 * * * \\
(0.001)\end{array}$ & $\begin{array}{c}0.044 * * * \\
(0.001)\end{array}$ \\
\hline Cash Flow/(K+L) & & & & & & $\begin{array}{l}3.245^{* * * *} \\
(0.017)\end{array}$ & $\begin{array}{c}3.246^{* * *} \\
(0.017)\end{array}$ \\
\hline Sales Growth & & & & & & $\begin{array}{c}0.019 * * * \\
(0.003)\end{array}$ & $\begin{array}{c}0.019 * * * \\
(0.003)\end{array}$ \\
\hline Observations & 95,000 & 95,000 & 95,000 & 95,000 & 95,000 & 65,000 & 65,000 \\
\hline R-squared & 0.120 & 0.121 & 0.121 & 0.121 & 0.121 & 0.504 & 0.504 \\
\hline Firms & 5000 & 5000 & 5000 & 5000 & 5000 & 5000 & 5000 \\
\hline
\end{tabular}

Notes: The dependent variable is net investment measured as the DHS growth rate in the capital stock. All columns include a full set of firm and date fixed effects. Robust standard errors in parentheses, clustered by firm. Each observation is a firm-quarter from a 5,000 firm simulation panel. Each firm consists of 25 production units making investment decisions and independent first moment shocks common uncertainty shocks. The model is solved and simulated at a monthly frequency and aggregated to quarterly data. Short- and long-run uncertainty are measured as the average expected volatility of shocks to revenue-generation over the horizon indicated. Tobin's Q is measured as firm value divided by the stock of K and L. Cash flow is defined as revenue. Sales growth is measured as the revenue over the past four quarters, minus that over the previous four quarters, divided by the average of the two. All variables are winsorized at the 1 st and 99th percentiles. ${ }^{* * *} \mathrm{p}<0.01,{ }^{* *} \mathrm{p}<0.05,{ }^{*} \mathrm{p}<0.1$ 


\section{Table 8: Simulation Annual Net Investment and Hiring Under Short- and Long-run Uncertainty}

\begin{tabular}{|c|c|c|c|c|c|}
\hline \multirow{3}{*}{$\begin{array}{l}\text { Dependent Variable } \\
\text { Calibration }\end{array}$} & \multirow{3}{*}{$\begin{array}{c}1) \\
\text { Net } \\
\text { Investment } \\
\text { Baseline }\end{array}$} & \multirow{3}{*}{$\begin{array}{c}\text { (2) } \\
\text { Hiring } \\
\text { Baseline }\end{array}$} & (3) & (4) & $(5)$ \\
\hline & & & \multicolumn{3}{|c|}{ Net Investment - Hiring } \\
\hline & & & Baseline & Equal AC & $\begin{array}{l}\text { Equal Dep \& } \\
\text { AC }\end{array}$ \\
\hline Lag $\log (30 d$ Expected Vol.) & $\begin{array}{c}-0.130^{* * *} \\
(0.020)\end{array}$ & $\begin{array}{c}-0.106^{* * *} \\
(0.026)\end{array}$ & $\begin{array}{l}-0.023 \\
(0.026)\end{array}$ & $\begin{array}{c}0.150^{* * *} \\
(0.017)\end{array}$ & $\begin{array}{l}-0.012 \\
(0.012)\end{array}$ \\
\hline $\begin{array}{l}\text { Lag } \log (6 \mathrm{~m} \text { Expected Vol. })- \\
\log (30 \mathrm{~d} \text { Expected Vol. })\end{array}$ & $\begin{array}{c}-0.221 * * * \\
(0.050)\end{array}$ & $\begin{array}{l}-0.034 \\
(0.065)\end{array}$ & $\begin{array}{c}-0.183 * * * \\
(0.065)\end{array}$ & $\begin{array}{l}-0.083^{*} \\
(0.043)\end{array}$ & $\begin{array}{l}-0.044 \\
(0.030)\end{array}$ \\
\hline Lagged Tobin's Q & $\begin{array}{c}0.081 * * * \\
(0.003)\end{array}$ & $\begin{array}{c}0.136 * * * \\
(0.004)\end{array}$ & $\begin{array}{c}-0.054 * * * \\
(0.003)\end{array}$ & $\begin{array}{c}-0.023 * * * \\
(0.002)\end{array}$ & $\begin{array}{l}-0.000 \\
(0.001)\end{array}$ \\
\hline Cash Flow / $(\mathrm{K}+\mathrm{L})$ & $\begin{array}{c}1.385^{* * *} \\
(0.018)\end{array}$ & $\begin{array}{c}1.412 * * * \\
(0.025)\end{array}$ & $\begin{array}{l}-0.027 \\
(0.024)\end{array}$ & $\begin{array}{c}0.134 * * * \\
(0.017)\end{array}$ & $\begin{array}{l}-0.001 \\
(0.006)\end{array}$ \\
\hline Proportional Sales Growth & $\begin{array}{c}-0.043 * * * \\
(0.009)\end{array}$ & $\begin{array}{c}-0.053^{* * *} \\
(0.013)\end{array}$ & $\begin{array}{c}0.011 \\
(0.012)\end{array}$ & $\begin{array}{c}-0.066^{* * *} \\
(0.008)\end{array}$ & $\begin{array}{l}0.008 * \\
(0.004)\end{array}$ \\
\hline Observations & 20,000 & 20,000 & 20,000 & 20,000 & 20,000 \\
\hline R-squared & 0.746 & 0.670 & 0.097 & 0.104 & 0.061 \\
\hline Firms & 5000 & 5000 & 5000 & 5000 & 5000 \\
\hline Calibration Parameters: & & & & & \\
\hline K effective depreciation & 0.2 & 0.2 & 0.2 & 0.2 & 0.45 \\
\hline L effective depreciation & 0.45 & 0.45 & 0.45 & 0.45 & 0.45 \\
\hline $\mathrm{K}$ resale loss & 0.25 & 0.25 & 0.25 & 0.25 & 0.25 \\
\hline $\mathrm{L}$ resale loss & 0.125 & 0.125 & 0.125 & 0.25 & 0.25 \\
\hline
\end{tabular}

Notes: The dependent variables are net investment and hiring, defined as the (DHS) growth rates of capital and labor. Column (5) has equal adjustment costs on capital and labor, and column (6) additionally has equal depreciation. All columns have a full set of firm and time fixed-effects. Robust standard errors in parentheses, clustered by firm. Each observation is a firm-year from a 5,000 firm simulation panel. Each firm consists of 25 production units making investment decisions subject to independent first moment shocks and common uncertainty shocks. The model is solved and simulated at a monthly frequency and aggregated to annual data. Short- and long-run uncertainty are measured on the monthly data as the average expected volatility of first moment shocks over the next 30 days and 6 months, respectively. When aggregating to annual data, we take for a given year the average short- and long-run uncertainty over the last quarter of the year. Tobin's Q is measured as firm value divided by the stock of $\mathrm{K}$ and $\mathrm{L}$. Cash flow is defined as revenue. All growth variables are constructed as the current value minus the previous year's value, divided by the average of the two. All variables are winsorized at the 1 st and 99 th percentiles. $* * * p<0.01, * * \mathrm{p}<0.05, * \mathrm{p}<0.1$ 


\section{Appendix Table 1: Baseline Calibration}

\begin{tabular}{cccc}
\hline \hline Parameter & Description & Value & Notes \\
\hline $\mathbf{1} /(\mathbf{1}+\mathbf{r})$ & discount rate & .996 & $\mathrm{r}=0.05$, annually \\
$\boldsymbol{\alpha}_{\mathbf{k}}, \boldsymbol{\alpha}_{\mathbf{l}}$ & revenue elasticity of K, L & .4 & CRS and 25\% markups \\
$\boldsymbol{\sigma}_{\mathbf{s l}}, \boldsymbol{\sigma}_{\mathbf{l l}}$ & low volatility state for $\sigma_{\mathrm{s}}$ and $\sigma_{1}$ & .24 & $33 \%$ monthly in LL state \\
$\boldsymbol{\sigma}_{\mathbf{s h}}, \boldsymbol{\sigma}_{\mathbf{l h}}$ & high volatility state for $\sigma_{\mathrm{s}}$ and $\sigma_{1}$ & .46 & $66 \%$ monthly in HH state \\
$\boldsymbol{\rho}_{\mathbf{s}}$ & monthly persistence of $\sigma_{\mathrm{s}}$ & .85 & annual autocorrelation .15 \\
$\boldsymbol{\rho}_{\mathbf{l}}$ & monthly persistence of $\sigma_{\mathbf{l}}$ & .95 & annual autocorrelation .49 \\
$\boldsymbol{\delta}_{\mathbf{k}}$ & K effective monthly depreciation & .018 & $20 \%$ annual depreciation \\
$\boldsymbol{\delta}_{\mathbf{l}}$ & L effective monthly depreciation & .035 & $45 \%$ annual depreciation \\
$\boldsymbol{\gamma}_{\mathbf{k}}$ & K resale loss & .25 & 25\% resale loss, conventional value \\
$\boldsymbol{\gamma}_{\mathbf{l}}$ & L resale loss & .125 & $0.5 \gamma_{\mathrm{k}}$ \\
$\mathbf{F}_{\mathbf{k}}$ & fixed K adjustment costs & .01 & N/A \\
$\mathbf{F}_{\mathbf{l}}$ & fixed L adjustment costs & .01 & N/A \\
$\boldsymbol{\rho}_{\mathbf{A}}$ & monthly autocorrelation of log(A) & .983 & .95 quarterly, Khan \& Thomas (2008)
\end{tabular}

Notes: Parameters used in the baseline calibration of the two-factor simulation model analyzed in Section 5. 
Appendix Table 2: Summary Statistics

\begin{tabular}{|c|c|c|c|c|c|}
\hline \multicolumn{3}{|c|}{ ANNUAL SAMPLE } & \multicolumn{3}{|c|}{ Q QUARTERLY SAMPLE } \\
\hline & Mean & SD & & Mean & SD \\
\hline Total Assets (\$M) & 5,763 & 14,058 & Total Assets (\$M) & 4826 & 11,772 \\
\hline Capital Expenditures (\$M) & 269.2 & 585.2 & Capital Expenditures (\$M) & 57.83 & 125.8 \\
\hline Sales (\$M) & 4,166 & 8,044 & Sales $(\$ M)$ & 952.3 & 1,910 \\
\hline Cash Flow / Assets & 0.0918 & 0.1539 & Cash Flow / Assets & 0.0210 & 0.0485 \\
\hline PPENT (\$M) & 1,540 & 3,491 & PPENT (\$M) & 1,336 & 3,096 \\
\hline Lagged Tobin's Q & 2.058 & 1.875 & Lagged Tobin's Q & 2.036 & 1.883 \\
\hline Sales Growth & 0.0974 & 0.3039 & Sales Growth & .1273 & 0.2960 \\
\hline Lagged $\log (30$ day IVOL) & 3.902 & 0.4468 & Lagged log(30day IVOL) & 3.866 & 0.4353 \\
\hline Lagged $\log (6 \mathrm{~m}$ IVOL $)$ & 3.860 & 0.4240 & Lagged $\log (6 \mathrm{~m}$ IVOL) & 3.821 & 0.4167 \\
\hline CAPX/PPENT & 0.3551 & 0.4237 & CAPX/PPENT & 0.0818 & 0.0916 \\
\hline Employment Growth & 0.0548 & 0.2259 & R\&D Expense (\$M) & 30.94 & 80.16 \\
\hline Employees ('000s) & 18.27 & 40.60 & R\&D Growth & .0101 & .6480 \\
\hline $\mathbf{N}$ & \multicolumn{2}{|c|}{25,224} & $\mathbf{N}$ & \multicolumn{2}{|c|}{103,900} \\
\hline Date Range: 1997-2013 & & & Date Range: 1996Q2 - 2013Q & & \\
\hline
\end{tabular}

Notes: Summary statistics for the baseline regressions, columns (1) and (4) of Table 3, respectively for the annual and quarterly samples. Data is from Compustat North America Fundamentals Quarterly and Annual matched with implied volatility data from Option Metrics. Cash flow is defined as operating income. Tobin's Q is measured as the sum of market value, preferred stock capital, current liabilities and long term debt, all divided by the book value of assets. All growth variables measured as the change between the value in the current and the previous year, divided by the average of the two. Implied volatility by horizon is measured as the average for a firm-quarter, where in the annual sample we identify the implied volatility in a given fiscal year with the average of the last quarter. All variables are winsorized at the $1^{\text {st }}$ and $99^{\text {th }}$ percentiles. 
Appendix Table 3: What types of firms have non-missing implied volatility? (OLS)

\begin{tabular}{|c|c|c|c|c|c|c|c|c|c|}
\hline & (1) & (2) & (3) & (4) & (5) & (6) & (7) & (8) & (9) \\
\hline Dependent Variable & \multicolumn{9}{|c|}{ 1(30-day Implied Volatility Nonmissing) } \\
\hline $\log$ (Quarterly Sales) & $\begin{array}{c}0.089 * * * \\
(0.001)\end{array}$ & & & $\begin{array}{c}0.097 * * * \\
(0.001)\end{array}$ & $\begin{array}{c}0.018 * * * \\
(0.002)\end{array}$ & $\begin{array}{c}0.085^{* * * *} \\
(0.001)\end{array}$ & $\begin{array}{c}0.014 * * * \\
(0.002)\end{array}$ & $\begin{array}{c}0.083 * * * \\
(0.004)\end{array}$ & $\begin{array}{c}0.019 * * * \\
(0.003)\end{array}$ \\
\hline Sales Growth & & $\begin{array}{c}0.041 * * * \\
(0.010)\end{array}$ & & $\begin{array}{c}0.078 * * * \\
(0.008)\end{array}$ & $\begin{array}{c}0.042 * * * \\
(0.006)\end{array}$ & $\begin{array}{c}0.050 * * * \\
(0.006)\end{array}$ & $\begin{array}{c}0.045^{* * *} * \\
(0.008)\end{array}$ & $\begin{array}{c}-0.011 * * * \\
(0.003)\end{array}$ & $\begin{array}{c}0.034 * * * \\
(0.003)\end{array}$ \\
\hline Lagged $\log (91-$ day Realized Vol.) & & & $\begin{array}{c}-0.071 * * * \\
(0.005)\end{array}$ & & $\begin{array}{c}-0.032 * * * \\
(0.005)\end{array}$ & & $\begin{array}{c}-0.098 * * * \\
(0.008)\end{array}$ & & $\begin{array}{c}-0.022 * * * \\
(0.004)\end{array}$ \\
\hline Years in Sample & 2012 & 2012 & 2012 & 2012 & 2012 & 2002 & 2002 & $2000-2013$ & $2000-2013$ \\
\hline R-squared & 0.228 & 0.002 & 0.036 & 0.241 & 0.078 & 0.192 & 0.103 & 0.748 & 0.298 \\
\hline Dependent Variable & \multicolumn{9}{|c|}{ 1(6-month Implied Volatility Nonmissing) } \\
\hline $\log$ (Quarterly Sales) & $\begin{array}{c}0.089 * * * \\
(0.001)\end{array}$ & & & $\begin{array}{c}0.097 * * * \\
(0.001)\end{array}$ & $\begin{array}{c}0.020 * * * \\
(0.002)\end{array}$ & $\begin{array}{c}0.085 * * * \\
(0.001)\end{array}$ & $\begin{array}{c}0.018 * * * \\
(0.002)\end{array}$ & $\begin{array}{c}0.082 * * * \\
(0.004)\end{array}$ & $\begin{array}{c}0.022 * * * \\
(0.003)\end{array}$ \\
\hline Sales Growth & & $\begin{array}{c}0.041 * * * \\
(0.010)\end{array}$ & & $\begin{array}{c}0.079 * * * \\
(0.008)\end{array}$ & $\begin{array}{c}0.043 * * * \\
(0.007)\end{array}$ & $\begin{array}{c}0.051 * * * \\
(0.006)\end{array}$ & $\begin{array}{c}0.051 * * * \\
(0.009)\end{array}$ & $\begin{array}{c}-0.008 * * * \\
(0.003)\end{array}$ & $\begin{array}{c}0.041 * * * \\
(0.003)\end{array}$ \\
\hline Lagged $\log (91$-day Realized Vol.) & & & $\begin{array}{c}-0.070 * * * \\
(0.006)\end{array}$ & & $\begin{array}{c}-0.026 * * * \\
(0.005)\end{array}$ & & $\begin{array}{c}-0.110 * * * \\
(0.010)\end{array}$ & & $\begin{array}{c}-0.017 * * * \\
(0.005)\end{array}$ \\
\hline R-squared & 0.227 & 0.002 & 0.028 & 0.240 & 0.070 & 0.193 & 0.105 & 0.744 & 0.331 \\
\hline Date Fixed Effects & $\mathrm{N}$ & $\mathrm{N}$ & $\mathrm{N}$ & $\mathrm{N}$ & $\mathrm{N}$ & $\mathrm{N}$ & $\mathrm{N}$ & $\mathrm{Y}$ & $\mathrm{Y}$ \\
\hline Firm Fixed Effects & $\mathrm{N}$ & $\mathrm{N}$ & $\mathrm{N}$ & $\mathrm{N}$ & $\mathrm{N}$ & $\mathrm{N}$ & $\mathrm{N}$ & Y & $\mathrm{Y}$ \\
\hline Years in Sample & 2012 & 2012 & 2012 & 2012 & 2012 & 2002 & 2002 & $2000-2013$ & 2000-2013 \\
\hline Standard Errors & Robust & Robust & Robust & Robust & Robust & Robust & Robust & $\begin{array}{c}\text { Cluster } \\
\text { Firm }\end{array}$ & $\begin{array}{l}\text { Cluster } \\
\text { Firm }\end{array}$ \\
\hline Observations & 15,501 & 13,930 & 9,337 & 13,815 & 8,718 & 19,065 & 6,348 & 222,194 & 95,619 \\
\hline
\end{tabular}

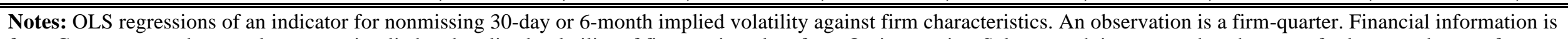

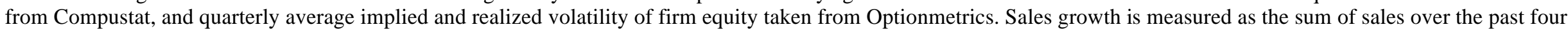

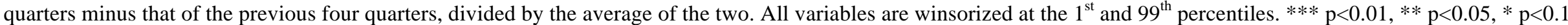




\section{Figure 1: Fluctuations in the VIX}

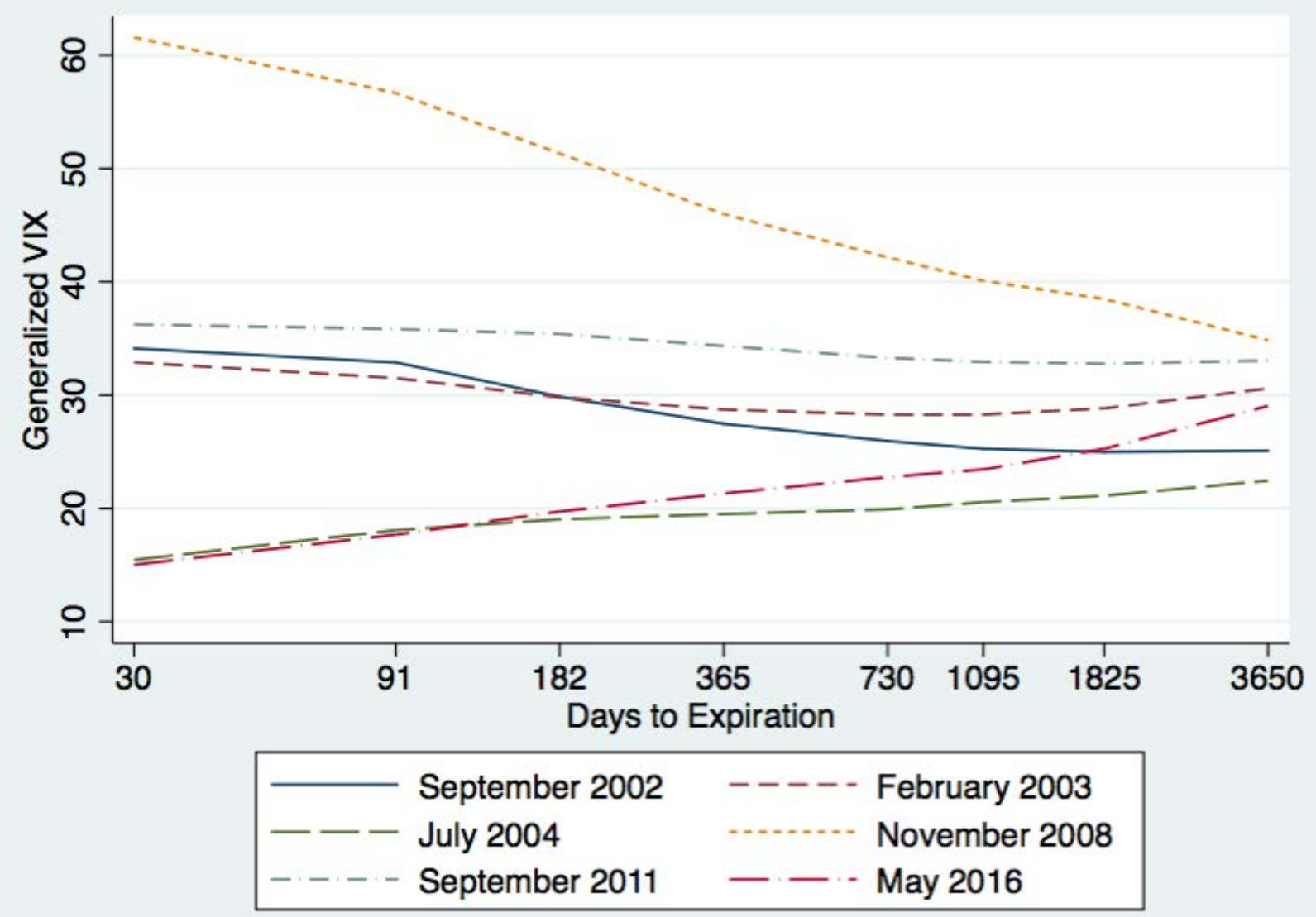

Notes: Average of the generalized VIX for the indicated month, by days to expiration measured on a logarithmic scale. The generalized VIX uses the formula used for the "true" VIX (a model-free measure of the 30-day implied variance on the S\&P 500) for horizons other than the standard 30 days. Source: Goldman Sachs. 
Figure 2: Predicting long-run VIX with 30-day and 6-month VIX

\section{A. 2-year VIX}

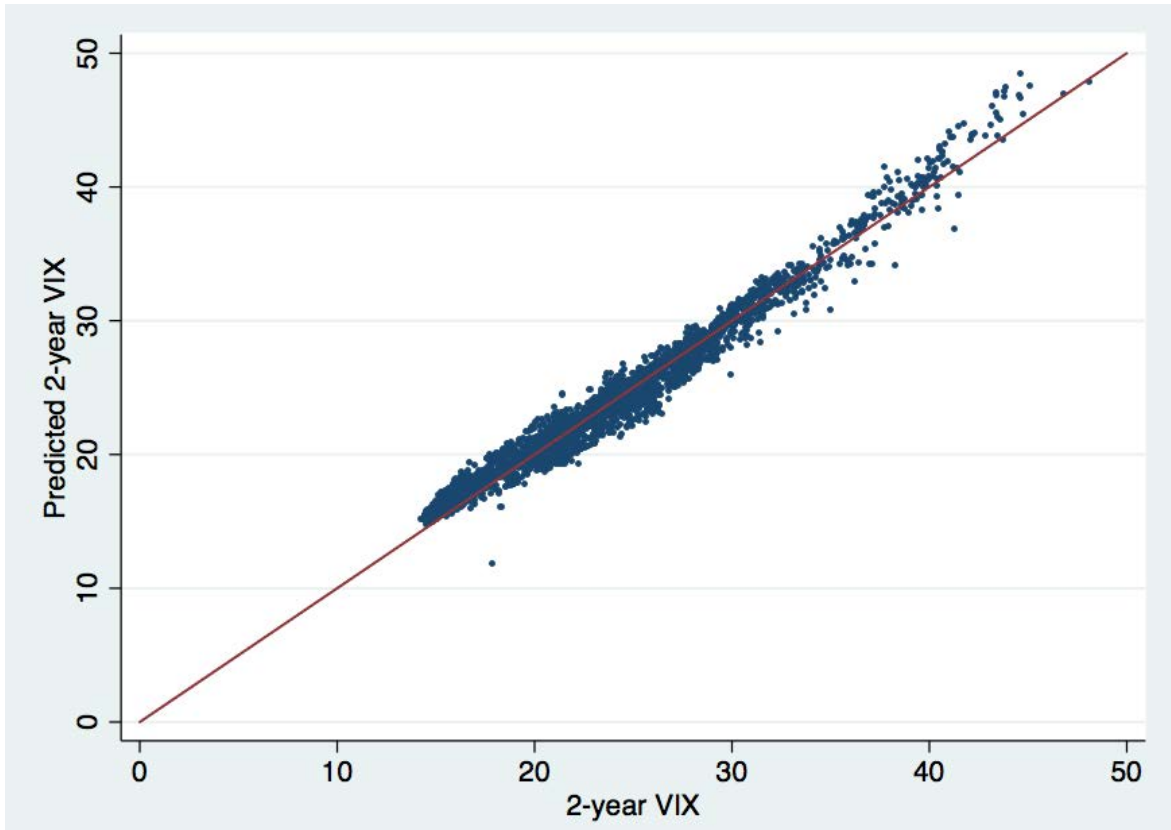

Notes: This figure plots the fitted values from a regression of daily observations of 2-year VIX on a constant, and the same day's 30-day and 6-month VIX. Data obtained from Goldman Sachs. $\mathrm{R}^{2}=.97$

\section{B. 5-year VIX}

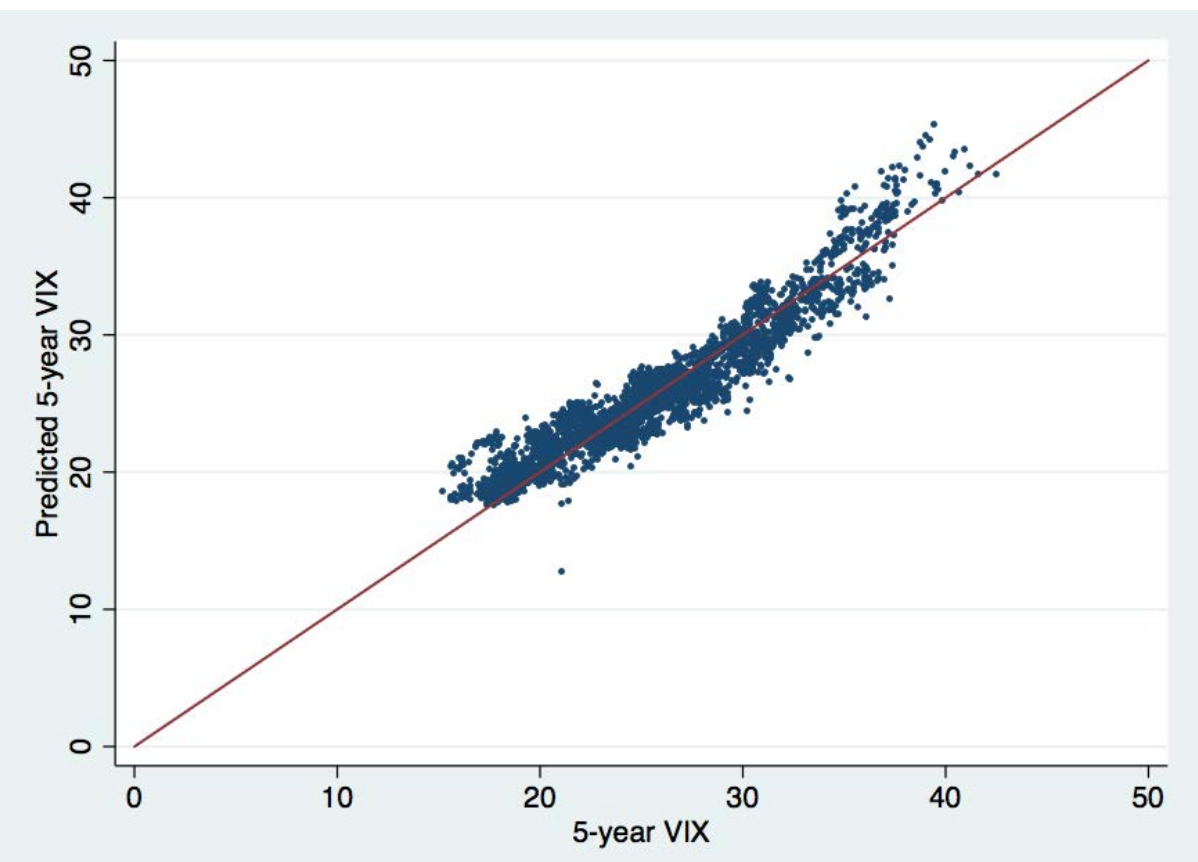

Notes: This figure plots the fitted values from a regression of daily observations of 2-year VIX on a constant, and the same day's 30-day and 6-month VIX. Data obtained from Goldman Sachs. $\mathrm{R}^{2}=.90$ 